\title{
Gold and platinum alkynyl complexes for biomedical applications
}

Elena Cerrada, Vanesa Fernández-Moreira, M. Concepción Gimeno ${ }^{1}$

Departamento de Química Inorgánica, Instituto de Síntesis Química y Catálisis Homogénea-ISQCH, Universidad de Zaragoza-C.S.I.C., Zaragoza, Spain

${ }^{1}$ Corresponding author: e-mail address: gimeno@unizar.es

\section{Contents}

1. Introduction 3

2. Gold alkynyl derivatives 5

2.1 Alkynyl complexes with triphenylphosphane as ancillary ligand 6

2.2 Alkynyl complexes with different phosphanes as ancillary ligands 8

2.3 Polynuclear gold alkynyl derivatives 12

2.4 Alkynyl gold derivatives with fluorophore ligands 13

$\begin{array}{ll}2.5 \text { Alkynyl carbene gold derivatives } & 16\end{array}$

3. Platinum alkynyl derivatives 17

3.1 Glycosylated alkynyl platinum complexes with terpyridine ligands 17

3.2 Alkynyl platinum complexes with COD ligands 18

3.3 Alkynyl platinum complexes with planar polyaromatic ligands 20

3.4 Dinuclear alkynyl platinum complexes 22

3.5 Alkynyl platinum complexes as photosensitizers (PSs) 22

3.6 Dual alkynyl platinum-based photosensitizers and photoimaging agents 24

4. Conclusions 26

Acknowledgments $\quad 27$

$\begin{array}{ll}\text { References } & 27\end{array}$

\section{Abbreviations}

A2780

A2780cisR

A549

Ar

BALC/c

Bipy

BODIPY

BT474 cisplatin sensitive ovarian cancer cell line cisplatin resistant ovarian cancer cell line lung adenocarcinoma cells

aryl albino, laboratory-bred strain of the house mouse 2, 2'-bipyridine 4,4-difluoro-bora-3a,4a-diaza-s-indacene human breast carcinoma cells 


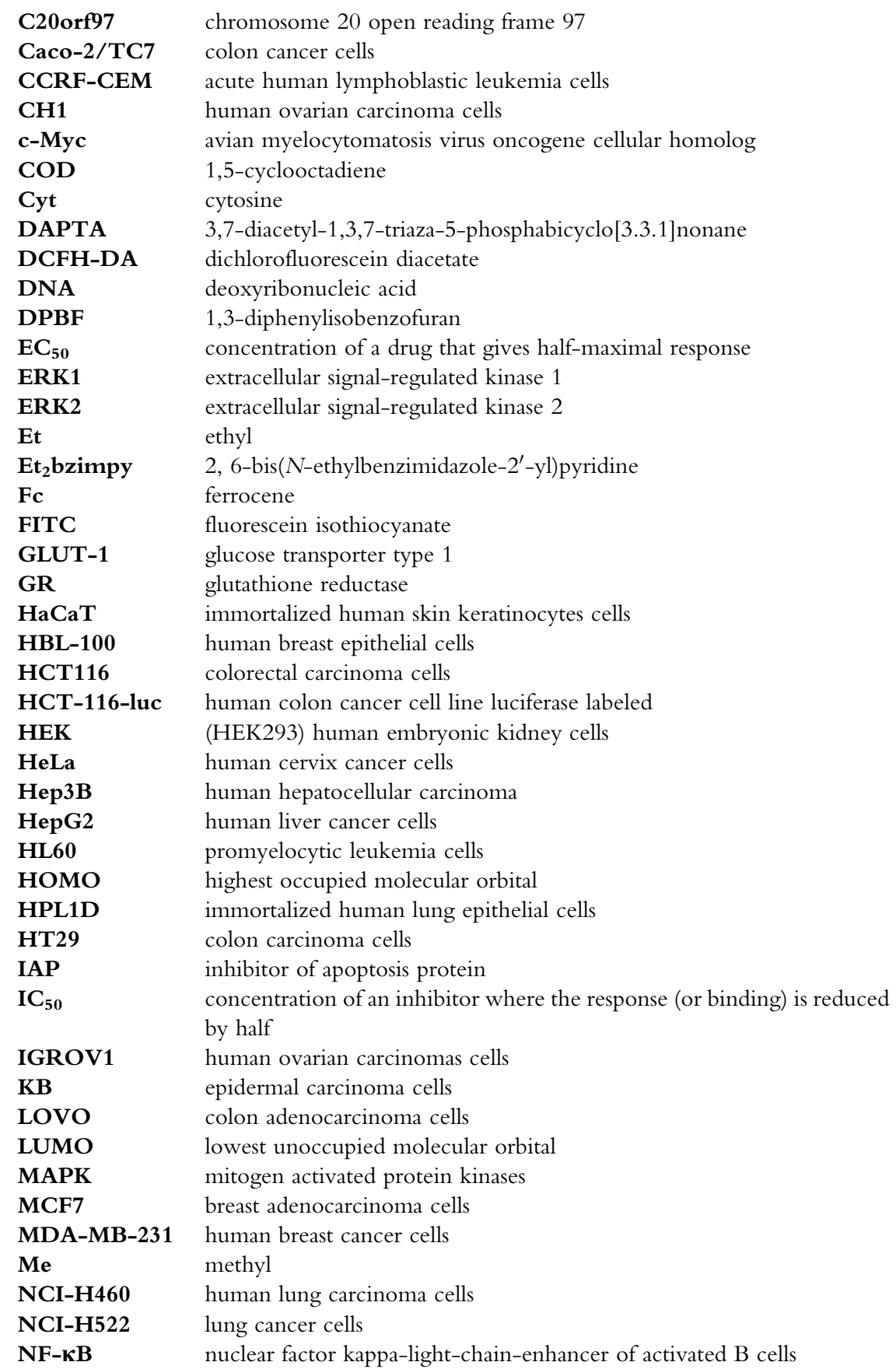




\begin{tabular}{|c|c|}
\hline NHC & $N$-heterocyclic carbene \\
\hline NIR & near-infrared \\
\hline NSCLC & non-small cell lung cancer \\
\hline PARP & poly-ADP(adenosine diphosphate)-Ribose Polymerase \\
\hline pBR322 & plasmid \\
\hline PC3 & prostate adenocarcinoma cells \\
\hline PCNA & proliferating cell nuclear antigen \\
\hline PDT & photodynamic therapy \\
\hline PEA15 & phospho-enriched protein in astrocytes $15 \mathrm{kDa}$ \\
\hline PEG & polyethylene glicol \\
\hline Ph & phenyl \\
\hline PI & propidium iodide \\
\hline PSs & photosensitizers \\
\hline PTA & 1,3,5-triaza-7-phosphaadamantane \\
\hline RC124 & human kidney cells \\
\hline RIP-1 & receptor interacting protein 1 \\
\hline ROS & reactive oxygen species \\
\hline SAR & structure-activity relationship \\
\hline SF-268 & human brain carcinoma cells \\
\hline SKHep-1 & human hepatoma cell line \\
\hline SKOV3 & human ovarian carcinoma cells \\
\hline STK15 & centrosome-associated serine/threonine oncogenic kinase \\
\hline SW480 & human ovarian carcinoma cells \\
\hline Terpy & $2,2^{\prime}: 6^{\prime}, 2^{\prime \prime}$-terpyridine \\
\hline TNF & tumor necrosis factor \\
\hline TPPTS & triphenylphosphane trisulfonated \\
\hline TrxR & thioredoxin reductase \\
\hline
\end{tabular}

\section{Introduction}

The study of transition-metal alkynyl complexes has been a very active area of research for many years, not only from the organometallic point of view but also for their use in luminescence, catalysis or material science. ${ }^{1,2}$ For example, oligomeric or polymeric alkynyl species have particularly promising electronic and structural properties, which include nonlinear optical effects, ${ }^{3,4}$ luminescence, ${ }^{5}$ electronic communication as molecular wires, ${ }^{2}$ and liquid crystallinity. ${ }^{6}$ These properties and relevance of the alkynyl ligands in supramolecular chemistry are based on three special characteristics: their linear structure, their high stability, and their $\pi$-electron conjugation.

The $\mathrm{C} \equiv \mathrm{C}$ bond also constitutes a focal point for different reactivity studies (Fig. 1). The first one is the formation of cluster compounds in which the alkynyl ligand bridges multiple metal centers, ${ }^{7}$ providing the final species 


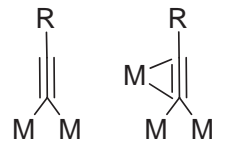

Alkynyl clusters<smiles>[R]C([R])=C=[W]</smiles>

Alkynyl transformation
$M+1||_{R}^{R} M-1||_{R}^{M}$

Intermediates

Fig. 1 Some binding modes of the alkynyl ligand.

with interesting luminescent properties. ${ }^{8,9}$ Alkyne derivatives can undergo several transformations into other interesting species such as vinylidene, allenylidene, or cummulenylidene, for which several examples with different metal centers have been reported. ${ }^{10,11}$ Additionally, in many organic transformations the alkyne precursors undergo addition or cyclization reactions in the present of a metal catalyst for which interesting $\mathrm{M}-\mathrm{C}$ intermediates have been proposed. ${ }^{12}$

Alkynyl ligands can be regarded as isoelectronic with $\mathrm{C} \equiv \mathrm{N}, \mathrm{C} \equiv \mathrm{O}$, and $\mathrm{N}_{2}$, and can also be comparable to a pseudohalide because of the similar behavior in complex formation and precipitation reactions. Thus, the chemistry of alkynyl transition-metal complexes can be regarded as classical coordination chemistry, albeit being also part of organometallic chemistry. ${ }^{13}$ Alkynyl ligands can be interpreted as being good $\sigma$ - and $\pi$-donors and poor $\pi$ acceptors. This has been corroborated by Extended Hückel band calculations and photoelectron spectroscopic measurements, which showed that the band gap between the HOMO metal d orbitals and the LUMO $\pi^{*}$ alkynyl orbitals is too large (ca. $15 \mathrm{eV}$ ) for $\pi$-accepting behavior, unless strong $\pi$-acceptor substituents in conjugation with the alkynyl unit are present. ${ }^{14}$

However, in spite of the huge amount of possibilities for alkynyl ligands in the synthesis of metal complexes and potential applications, it was not until recently that metal complexes were studied for their biological properties; specifically for gold and platinum compounds. The medicinal chemistry of metallic complexes actually started with the discovery of the high activity of cis-diaminodicloroplatinum(II) (cisplatin) toward several types of cancers. Subsequent platinum drugs were approved as chemotherapeutic agents ${ }^{15}$ but because of the several drawbacks that the platinum drugs presented, such as undesired side effects, drug resistance and the narrow effectivity scope toward different tumors, research into other metal complexes as potential metallodrugs was impulsed. ${ }^{16,17}$ Gold compounds are among the most studied metal-based drug for this purpose, and many derivatives have been reported with antitumor properties.

Stability of the gold derivatives in the biological media is an important feature for the development of gold-based drugs. For that reason complexes 


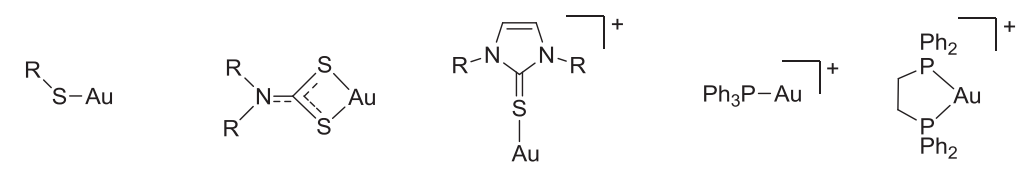

Thiolate

Dithiocarbamate

Thiourea

Phosphane

Diphosphane

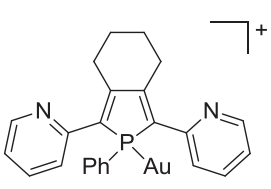

Phosphole

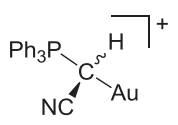

Ylide

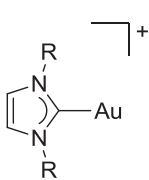

Carbene

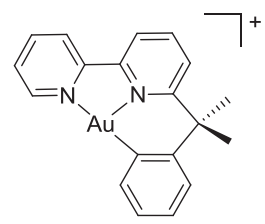

Cyclometalated ligand

Fig. 2 Gold-based complexes with different ligands that exhibit cytotoxic activity.

bearing strong ligand-metal bonds that allow a better stability against dissociation in the biological media have been studied. Some examples of these ligands (Fig. 2) are thiolates, ${ }^{20,21}$ dithiocarbamates, ${ }^{22,23}$ thioureas, $^{24}$ phosphanes, $^{25}$ phospholes, ${ }^{26} \mathrm{~N}$-heterocyclic carbenes, ${ }^{27}$ ylides ${ }^{28}$ or cyclometallated ligands, ${ }^{29}$ for which many metal complexes have been reported in the last decades with excellent biological activity.

It is noteworthy that, despite the great stability shown by the metalcarbon bonds in the alkyne ligands for gold and platinum, it was not until recently that these complexes were studied for anticancer properties. Additionally, their high stability to dissociation could exhibit a different mechanism that those shown by gold or platinum species. In these sense whereas platinum derivatives have the DNA as the main biological target, gold presents different pathways for the cytotoxicity, and relevant goldprotein interactions, mainly those bearing cysteine and/or selenocysteine moieties, could be the potential biological targets responsible for the cytotoxic effects of gold compounds.

This review covers the chemistry of gold and platinum complexes bearing alkynyl ligands that present antitumor activity. The type of complexes which exhibit antiproliferative properties, together with the different studies performed to elucidate the mechanism of action will be commented.

\section{Gold alkynyl derivatives}

As has been commented above, organometallic gold complexes, including $N$-heterocyclic carbene and cyclometallated species with antiproliferative activity have been deeply studied, but in contrast organometallic 
complexes with alkynyl ligands are much less represented. Most of the synthesized complexes are alkynyl or propargyl species bearing different substituents, and with phosphanes as ancillary ligands. Such complexes tend to exhibit remarkable stability due to the high bond dissociation energies around the gold center. Alkynyl ligands are strong $\sigma$ - and $\pi$-donors and recent studies combining photoelectron spectroscopy and theoretical calculations found the gold-carbon bond in alkynyl gold complexes to be one of the strongest gold-ligand bonds known. ${ }^{32}$ The high stability of these complexes under physiological conditions might overcome one of the main issues in the development of new metallodrugs: their tendency to decompose before reaching the target due to reaction with biologically occurring reducing agents such as thiols.

\subsection{Alkynyl complexes with triphenylphosphane as ancillary ligand}

The first two examples of alkynyl derivatives with antitumor activity were described almost simultaneously in 2009. Thus, the two diethynylfluorene gold(I) complexes with triphenylphosphane (1 and $\mathbf{2}$ ) depicted in Fig. 3 have been studied for their antitumor activity against three human carcinoma cell lines (Hep3B human hepatocellular carcinoma, SKHep-1 hepatoma and MDA-MB-231 human breast cancer cells). ${ }^{33}$ The presence of carbonyl group in the diethynylfluorene moiety seems to be essential for the antiproliferative activity, since no cytotoxicity was observed in the case of complex 1 but better cytotoxicity than that found in cisplatin was exerted by complex 2. In fact, the latter complex was able to induce intracellular reactive oxygen species (ROS) on Hep3B human hepatocellular carcinoma cells and reduce the mean tumor volume in treated mice with limited toxicology effects, as no necrotic features were found in the livers and kidneys examined after mice autopsy. Phosphane gold(I) propargyl ethers such as 7-chloro-(4propargyloxy)quinoline (molecule derived from chloroquine, the most effective drug for malaria treatment), 1-propargyloxynaphthalene and 2-propargyloxybenzophenone (complexes 3-5, Fig. 3) were found to be active against ovarian and colon cancer cell lines (chemosensitive ovarian cancer $\mathrm{CH} 1$ and SKOV3, with intrinsic resistance to cisplatin and colon cancer cell line SW480). ${ }^{34}$ Similar IC $_{50}$ values were shown in both complexes and consequently none structure-activity relationship can be inferred.

Mononuclear alkynyl triphenylphosphane gold(I) derivatives (6-11, Fig. 3) with different alkyne ligands have shown strong antiproliferative activity with $\mathrm{IC}_{50}$ values between 0.8 and $12 \mu \mathrm{M}$ against MCF7 breast 


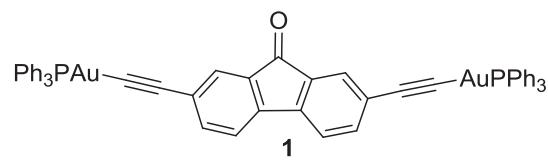<smiles>Clc1ccc2c(OCC#C[Al](c3ccccc3)c3ccccc3)ccnc2c1</smiles><smiles></smiles><smiles>O=C(c1ccccc1)C1CC=CC=C1OCC#C[TeH2]</smiles>

5

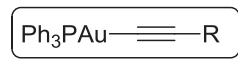

6-11

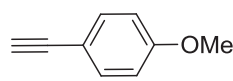

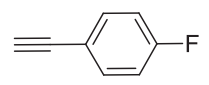

7

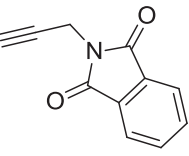

10
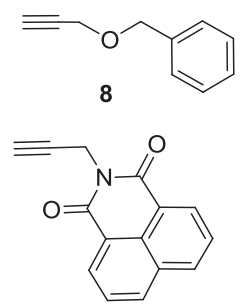

11

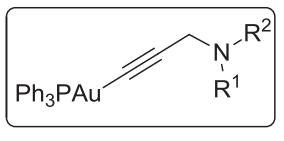

$12-14$<smiles>C#CCN(Cc1ccccc1)C(C)c1ccccc1</smiles>

12

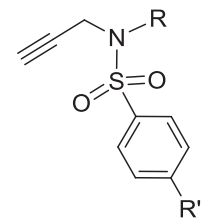

13a, $R=M e, R^{\prime}=M e$

13b, $R=P h, R^{\prime}=M e$

13c, $\mathrm{R}=\mathrm{Me}, \mathrm{R}^{\prime}=\mathrm{NO}_{2}$

13d, $R=M e, R^{\prime}=H$

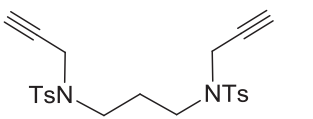

14

Fig. 3 Alkynyl triphenylphosphane gold(I) derivatives.

adenocarcinoma and HT29 colon carcinoma cells. ${ }^{35}$ Faster uptake of complexes with smaller alkynyl molecules could be concluded from cellular uptake studies by measuring the gold content inside HT29 cells by high resolution continuum source atomic absorption spectroscopy. These derivatives exhibited strong inhibition of the selenoenzyme thioredoxin reductase TrxR, besides low inhibition of the related enzyme glutathione reductase (GR), thus establishing high selectivity to TrxR compared to GR. These compounds have displayed significant anti-angiogenic effects in zebrafish embryos in addition to a decrease of tumor cell impedance 
and extracellular acidification, which points to mitochondria as a major target organelle, similarly to other gold metallodrugs. ${ }^{36-41}$ Complex 6 was selected for further studies ${ }^{42}$ that included tumor selectivity and mechanistic approaches related to protein kinases. Thus, microscopic live cell imaging revealed morphological changes in RC124 kidney cells during the first $6 \mathrm{~h}$ of exposure to complex 6 consistent with the presence of interactions of the gold compound with components of the cell surface or extracellular matrix. Incubation of $\mathbf{6}$ with HT29 colon cancer cells led to a significant and persistent activation of the mitogen activated kinases (MAPK) ERK1 and ERK2, both involved in growth factor signaling and consequently responsible to regulation of biological functions such as cell growth, differentiation and survival.

Coordination of the triphenylphosphane gold moiety to propargylic amine ligands (complexes 12-14, Fig. 3) led to a family of derivatives, ${ }^{43}$ in which the presence of different substituents on the nitrogen atom modulates their overall cytotoxic properties. Therefore, the most effective in inhibiting cell growth in HT29 human colorectal carcinoma, IGROV1 human ovarian carcinoma and HL60 promyelocytic leukemia cell line, were both complexes 13a and 13d with para-substituted benzene sulfonamide unit. However, they also showed significant cytotoxicity against nonmalignant human epithelial intestine cell line I407. Complex 13a caused cell cycle arrest in S phase for HT29 and IGROV1 cells and in the G0/G1 phase for HL60 with a well detectable fraction of DNA present as a sub-G1 peak, suggesting DNA fragmentation. These effects have been associated with an interaction with DNA, supported by the calculation of a dissociation constant of the complex with salmon sperm DNA in the sub-micromolar range. Conversely to that observed in the rest of the derivatives 12-14, complex 13a did not show any inhibitory effect on the thioredoxin reductase activity.

\subsection{Alkynyl complexes with different phosphanes as ancillary ligands}

In order to study the structure-activity relationship in this type of complexes, a systematic design of an extensive family of gold compounds has been described. ${ }^{44}$ Accordingly, the implication of electronic and steric factors in the antiproliferative activity and the inhibition of the thioredoxin reductase activity have been evaluated. Thus, the presence of different electrondonating moieties in para position of phenylacetylene and the use of a series of phosphanes with different degree of electron-donating properties, modifying the $\mathrm{R}$ group, lead to the preparation of a large number of phosphane 


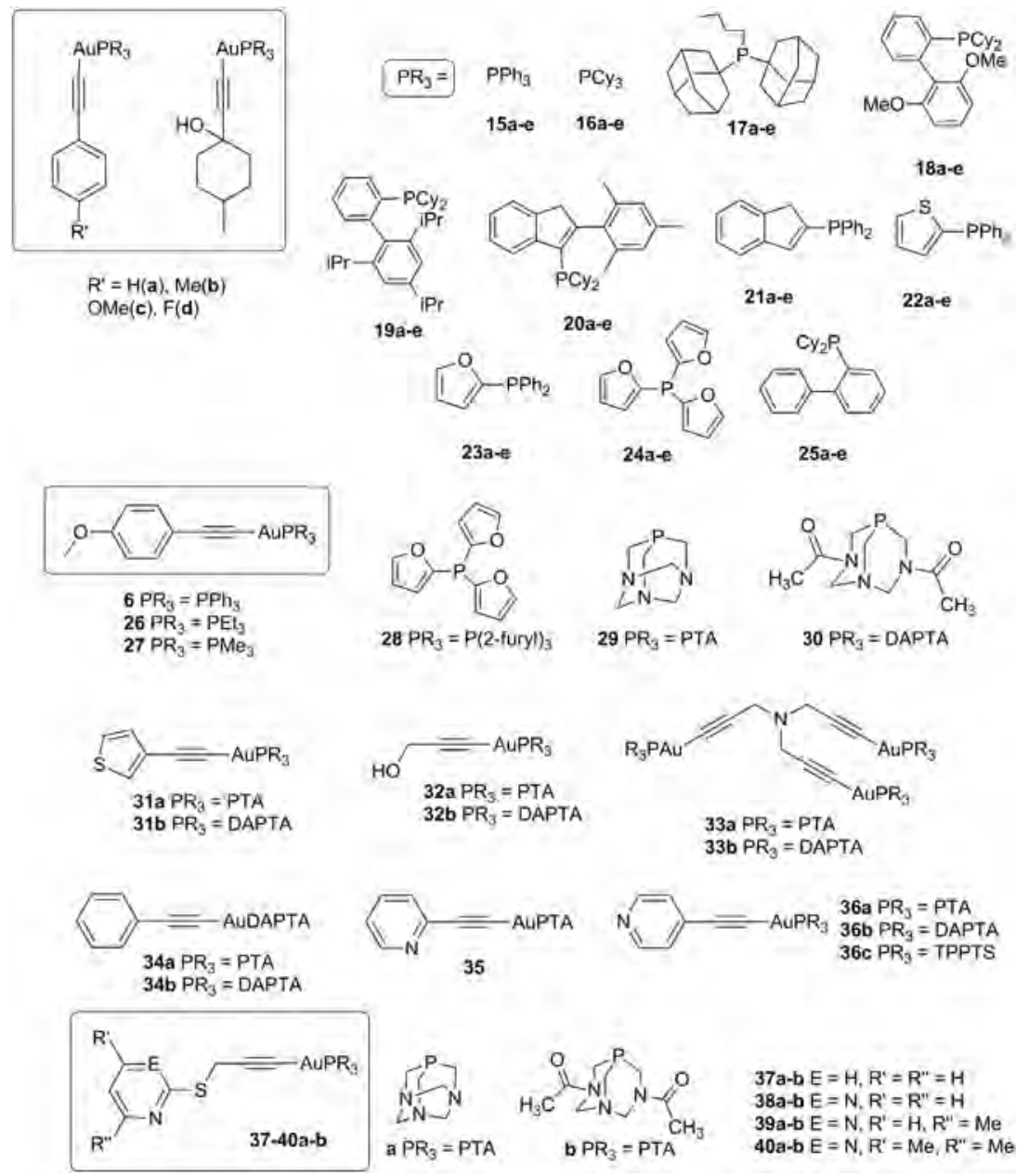

Fig. 4 Alkynyl derivatives with different phosphane molecules.

alkynyl gold(I) derivatives (complexes 15-25a-e, Fig. 4). It was observed that, in general, compounds with strong electron-donating moieties, which result in the delocalization of the metal active center, displayed high inhibition efficacy of TrxR activity, being complex 22c, with 4-methoxyphenylalkyne and thienyldiphenylphosphane as ligands, the most efficient, with $\mathrm{EC}_{50}$ (half maximal effective enzyme inhibition concentration) value of $2.8 \mathrm{nM}$. Moreover, complex 22c was able to inhibit TrxR through irreversible inactivation of redox-active selenylsulfide motif and with remarkable specificity, as derived from the low inhibition efficacy of 
the related enzyme glutathione (GR). The same complexes were able to reduce TrxR activity and showed high efficiency in the inhibition of cell proliferation of MCF7 breast adenocarcinoma and HT29 human colorectal carcinoma. Complex 22c displayed again the highest efficacy, with the lowest $\mathrm{IC}_{50}$ values $(0.03 \mu \mathrm{M}$ in MCF7 cells and $0.10 \mu \mathrm{M}$ in HT29 cells) in addition to other cell lines such as epidermal carcinoma cells $(\mathrm{KB})$, breast cancer cells (MDA and MB-231), human lung cancer cells (A549) and human cervical cancer cells (HeLa). Furthermore, 22c displayed much higher cytotoxicity to tumor cells than normal cells (human embryonic kidney cells and immortal hepatic cells) and the ability to reduce tumor volume in in vivo studies by using MCF7 cells xenografted BALC/c nude mice model.

With the aim to extend the structure-activity relationship to a family of compounds derived from 4-ethynylanisole, the complexes with different phosphanes including the water soluble molecules PTA (1,3,5-triaza-7-phosphaadamantane) and DAPTA (3,7-diacetyl-1,3,7-triaza-5-phosphabicyclo [3.3.1]nonane) (complex 6 and complexes 26-30, Fig. 4) have been described and screened for their biological properties. ${ }^{42}$ Complex 26 with triethylphosphane turned out to be the most active against HT29 colon carcinoma and MDA-MB-231 breast adenocarcinoma, with the lowest $\mathrm{IC}_{50}$ values in both cell lines. However the observed values were in a rather narrow range $(1-5 \mu \mathrm{M})$ and no conclusions concerning structure-activity relationship could be established. All the complexes were efficient inhibitors of thioredoxin reductase with $\mathrm{IC}_{50}$ values in the nanomolar range, with a linear correlation between the anticancer activity and the inhibition of this enzyme.

Water soluble alkynyl derivatives with the phosphanes PTA and DAPTA have been characterized as cytotoxic compounds against the cisplatin sensitive (A2780) and cisplatin-resistant (A2780cisR) human ovarian cancer cells (31-34, Fig. 4). ${ }^{45}$ The $\mathrm{IC}_{50}$ values for complexes $\mathbf{3 1 a}$ and $\mathbf{3 4 b}$ were similar in both cell lines and of the same order to those found in auranofin, which suggest these compounds can overcome the resistance to cisplatin supporting the hypothesis of a different mechanism of action of the gold derivatives. In fact, no interaction with DNA was detected after their incubation with the plasmid pBR322 DNA at $37^{\circ} \mathrm{C}$. Thanks to their luminescent properties, their cellular uptake has been determined by using epifluorescence microscopy, showing their effective and fast cell internalization. An in-depth analysis to determine the mechanism of action of some of these alkynyl phosphane derivatives has revealed the significance of the alkyne structure. Thus, the PTA counterpart 34a to the previously reported 
$\mathbf{3 4} \mathbf{b}$ as a cytotoxic complex to ovarian cancer cell lines, has demonstrated to display strong antiproliferative activity against colon cancer cells ${ }^{46} \mathrm{Caco}-2 /$ TC7, which seemed to be selective to normal enterocytes (Caco-2/TC7 spontaneously differentiate in culture in enterocyte-like cells). ${ }^{47}$ This cytotoxicity is due to the inhibition of the enzyme TrxR, which produces an increase in ROS levels leading to apoptosis induction by dissipation of mitochondrial membrane potential, release of cytochrome $c$ and indirectly by altering the balance between pro-apoptotic and anti-apoptotic proteins. Although the related PTA derivative 35, with 2-ethynylpyridine as alkyne ligand, displayed a similar $\mathrm{IC}_{50}$ value to that of complex $34 \mathbf{a}$ on colorectal adenocarcinoma Caco-2/TC7 cell line, the introduction of an additional $\mathrm{N}$ atom in the alkyne skeleton lead to different behavior against these cancerous cells. The main difference came from the abnormal ROS production, accompanied of a scarce inhibition of TrxR activity, which triggered TNF-induced necroptosis dependent of RIP-1 activation and NF- $\kappa B$ signaling. ${ }^{48}$ In addition, viability studies of Caco-2 spheroids (3D cell culture) in the presence of increasing concentration of complex 35 caused cell death in a tumor-like environment, suggesting the prevalence of antiproliferative properties into a living organism.

Lower effects against tumor cell growth (HT29 colon carcinoma and MDA-MB-231 breast cancer cells) were observed in complexes $\mathbf{3 6 a}-\mathbf{b},{ }^{49}$ or even no cytotoxicity in the case of $\mathbf{3 6} \mathbf{c}^{50}$ (with triphenylphosphane trisulfonated, TPPTS). These three compounds are structurally related to 35, where the position of the nitrogen atom has been changed. However they displayed different behavior toward cancer cells which reinforces the relevance of small changes in the complex structure.

A series of $S$-propargylthiopyridine and thiopyrimidine with gold complexes bearing the phosphanes PTA and DAPTA (37-40a-b, Fig. 4) have been reported ${ }^{51,52}$ as better cytotoxic derivatives than cisplatin against human colon cancer cell lines Caco-2/PD7 (from early passage) and Caco-2/TC7 (from late passage). No significant influence of the substituents of the alkyne moiety has been observed. However, a considerable difference in the antiproliferative activity was found depending on the phosphane, being more active complexes with the PTA ligand. Accordingly with these findings, higher cellular uptake was measured by ICP-MS analysis for the PTA derivatives, probably due to a worse permeability of the DAPTA ligand in comparison with PTA. Moderate values of the binding constant were obtained for the interaction of these compounds with bovine serum albumin (BSA) and a balanced relationship between lipophilicity and 
hydrophilicity could be inferred from the corresponding partition coefficient values between water and $n$-octanol. These results may imply an easy transport through multiple mixed water-lipid layers with a subsequent release to the target. Moreover, administration of complex 37a to athymic nude mice xenografted with human HCT-116-luc cancer cells lead to an increase in the mean survival time and life expectancy and moderate inhibition tumor growth without acute toxicity. ${ }^{52}$

\subsection{Polynuclear gold alkynyl derivatives}

Heterodinuclear and trinuclear gold(I) and copper(I) alkynyl complexes $(\mathbf{4 1} \mathbf{a}-\mathbf{b} \text { and } \mathbf{4 2} \mathbf{a}-\mathbf{b} \text {, Fig. } 5)^{51}$ derived from $37 \mathbf{a}-\mathbf{b}$ have remarkably improved their cytotoxicity compared to their precursors, with the best $\mathrm{IC}_{50}$ value of $0.2 \mathrm{nM}$ for the PTA compound 41a. This is not surprising because other bimetallic derivatives had shown an improvement in their antitumor activity in comparison with their mononuclear precursors, including Ti-M $(\mathrm{M}=\mathrm{Au}, \mathrm{Ru}, \mathrm{Pd}, \mathrm{Pt}), \mathrm{Au}-\mathrm{Ru}$ or Pt-Au combinations. ${ }^{53-58}$ However complexes $41 \mathbf{a}-\mathbf{b}$ comprised the first examples of bimetallic $\mathrm{Au}-\mathrm{Cu}$ species, also including alkynyl ligands. The interaction of both metals with different
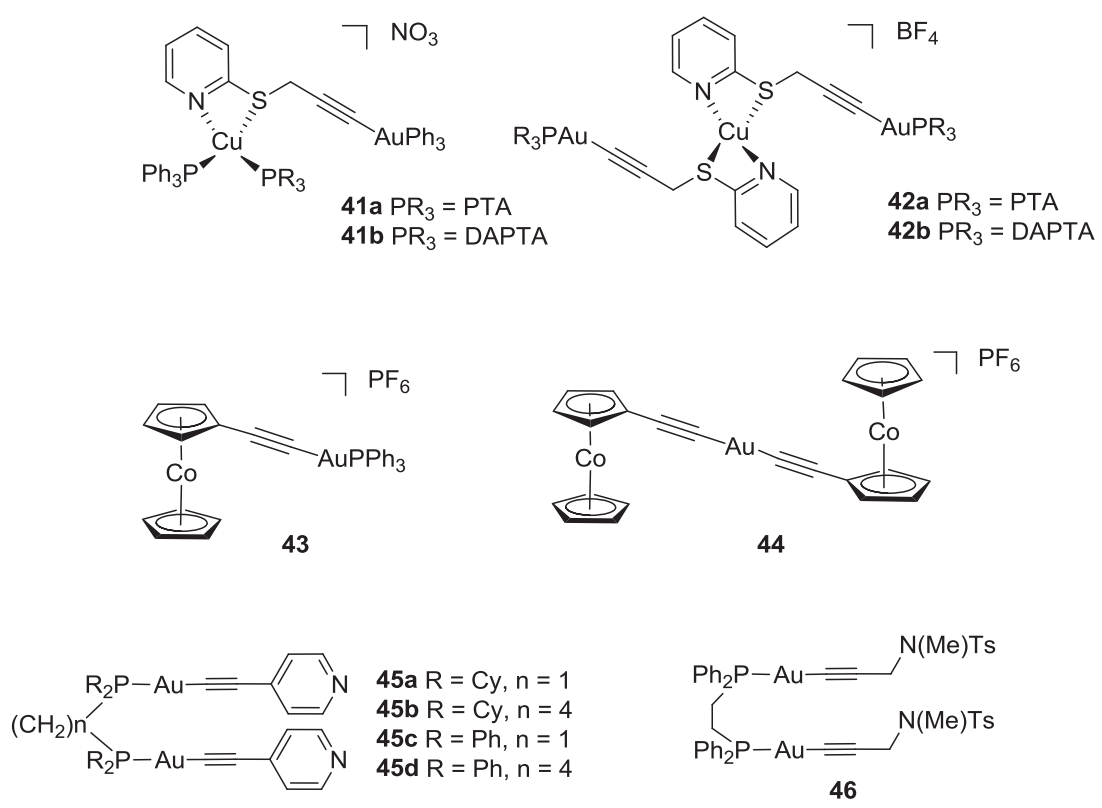

Fig. 5 Polynuclear alkynyl gold(I) complexes. 
biological targets seems to be the reason of the improved antiproliferative effect found in the reported polynuclear compounds.

Bildstein, Ott and coworkers ${ }^{59}$ have recently reported two cobalteceniumethynyl gold(I) derivatives (43 and 44, Fig. 5) but only the monoalkynyl gold complex $\mathbf{4 3}$ displayed antitumor effect in HT29 colon carcinoma and MDA-MB231 breast cancer cell lines, probably because of its effectivity in inhibiting TrxR activity. However, no selectivity was observed for the best complex, as its activity in non tumor cell line (RC124 human kidney) was similar to that measured in the cancerous cells. Unexpectedly, the dialkynyl derivative $\mathbf{4 3}$ was inactive against the cancerous cells and showed minor effects against the non tumor RC124 cells.

A family of dinuclear diphosphane gold(I) derivatives with 4ethynylpyridine $^{60}$ (45a-d, Fig. 5) has been described as highly cytotoxic complexes against MCF7 breast cancer and HT29 colon carcinoma cells. Only complexes with bis(diphenylphosphino)methane (dppm) and 1,4-bis (diphenylphosphino)butane (dppb) were described as active TrxR inhibitors. The counterpart diphosphanes with cyclohexyl groups led to complexes $\mathbf{4 5 a}-\mathbf{b}$ with low solubility in the biological media, which seems to be in accordance with the missing activity against the enzyme TrxR. Combination of 1,2-bis(diphenylphosphino)etane (dppe) with a propargyl amine afforded the dinuclear complex $\mathbf{4 6}$ as an effective inhibitor of TrxR. ${ }^{43}$ High selectivity was found in this case since it showed inactivity against nonmalignant epithelial intestinal cell line I407 and high cytotoxicity toward HL60 leukemia cell line, although lack of toxicity was found toward HT29 colon carcinoma cells and IGROV1 human ovarian carcinoma.

\subsection{Alkynyl gold derivatives with fluorophore ligands}

Fluorescence microscopy cell imaging has been shown as an excellent tool for visualization of drug cellular uptake and its biodistribution inside the cell, being possible to distinguish its localization in nucleus or other organelles within the cytoplasm. This information is relevant for the elucidation of structure-activity relationship. With this idea several luminescent alkynyl gold(I) derivatives have been designed with chromophore ligands by Pope and coworkers. ${ }^{61}$ Thus, the use of mono- and dipropargylated dihydroxyanthraquinones afforded mono- and dinuclear alkynyl complexes 47-49 (Fig. 6) that resulted highly cytotoxic against MCF7 breast adenocarcinoma ( $\left.\mathrm{IC}_{50} \approx 5 \mu \mathrm{M}\right)$, although less effective toward A549 lung adenocarcinoma, PC3 prostate adenocarcinoma and LOVO 


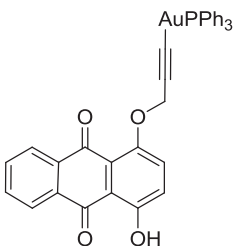

47

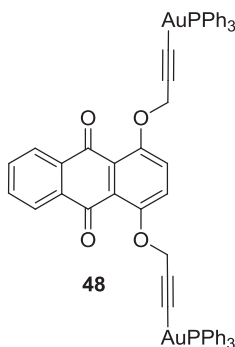

$\mathrm{AuPPh}_{3}$<smiles>[R16][R16]#CCOc1ccc2c([R])cc(=O)oc2c1</smiles>

51a $R^{\prime}=H, P_{3}=P T A$ $51 \mathrm{~b} \mathrm{R}^{\prime}=\mathrm{H}, \mathrm{PR}_{3}=$ DAPTA 51c $R^{\prime}=H, P_{3}=$ TPPTS 52a $R^{\prime}=M e, P_{3}=P T A$ 52b $\mathrm{R}^{\prime}=\mathrm{Me}, \mathrm{PR}_{3}=\mathrm{DAPTA}$

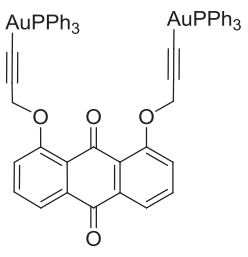

49<smiles>[R16][Y10]#CCOc1cc(=O)oc2ccccc12</smiles>

50a $\mathrm{PR}_{3}=\mathrm{PTA}$

$50 \mathrm{~b} \mathrm{PR}_{3}=\mathrm{DAPTA}$<smiles>[R]c1cc(=O)oc2cc(OC#C[Al]C#CCOc3ccc4c([R])cc(=O)oc4c3)ccc12</smiles><smiles>[R]c1ccc2occ(CCC(=O)NCC#C[C]([PH2+])[PH2+]c3ccccc3)c(=O)c2c1</smiles>

56a $\mathrm{R}=\mathrm{H}$

56b $\mathrm{R}=\mathrm{CH}=\mathrm{CHFc}$ 57

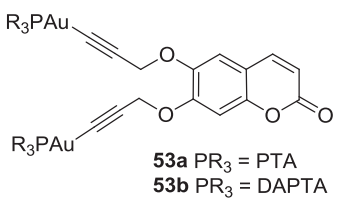

53b $\mathrm{PR}_{3}=$ DAPTA

55b $\mathrm{R}=\mathrm{Me}$<smiles>[R]c1ccc(-c2oc3ccc(Cl)cc3c(=O)c2OCC#CC(c2ccccc2)c2ccccc2)o1</smiles>

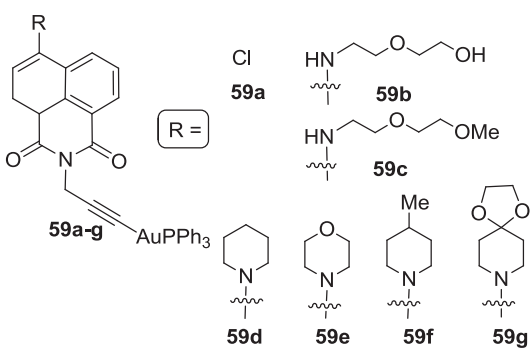
$58 b \mathrm{~b}=\mathrm{Me}$

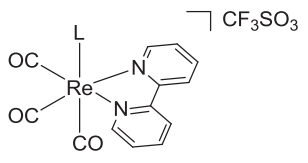<smiles>O=[W+]([O-])c1cccc(C#C[C](c2ccccc2)c2ccccc2)n1</smiles>

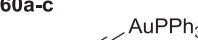<smiles></smiles>

$60 \mathrm{c}$

Fig. 6 Alkynyl gold derivatives with fluorophore moieties.

colon adenocarcinoma. These results are in accordance with the fact that MCF7 cancer cells have higher mitochondrial mass than many other immortal cell lines and the mitochondria are believed to be the intracellular target for most of the gold complexes. Better uptake of the gold complexes was observed in MCF7 cells in comparison to the free ligands using cellular 
imaging. The metallic derivatives were accumulated in a significant concentration across the entire cytoplasm including the organelles.

Coumarine derivatives were also used as chromophore ligands for delivering fluorescent cytotoxic species. In particular, a functionalized coumarine with a propynyloxy group at 4- or 7-position or two propynyloxy groups in the 6,7-positions, have afforded mono- and dinuclear gold(I) luminescent derivatives (50-53, Fig. 6) ${ }^{49,50}$ with the water soluble phosphanes PTA, DAPTA and TPPTS and the corresponding bis-alkynyl complexes (54 and 55, Fig. 6). ${ }^{49}$ The anionic compounds $\mathbf{5 4}$ and $\mathbf{5 5}$ displayed strong cytotoxicity against HT29 colon carcinoma and MDA-MB-231 breast cancer cells, with $\mathrm{IC}_{50}$ values ranging from 1.8 to $4.08 \mu \mathrm{M}$. This high activity has been attributed to the cation tetraphenylphosphonium, since the free coumarins were not cytotoxic and the salt $\mathrm{PPh}_{4} \mathrm{Cl}$ displayed high antitumor activity. The neutral phosphane complexes $\mathbf{5 0 - 5 3}$ exhibited from low to moderate cytotoxicities that in the case of $\mathbf{5 1} \mathbf{c}$ and $\mathbf{5 3} \mathbf{a}-\mathbf{b}$ were justified by the aggregation effects detected in aqueous solution that hampered their bioavailability. High inhibition of the enzyme thioredoxin reductase has been exerted by all the complexes, being more accentuated for the neutral derivatives.

A series of triphenylphosphane gold(I) derivatives with alkyne ligands derived from chromone (complexes 56a-b, Fig. 6) ${ }^{62}$ and flavone (complexes 57-58, Fig. 6) ${ }^{62,63}$ molecules have been described and biologically examined. Both chromones and flavones are plant metabolites of recognized medicinal importance and some examples of their metallic derivatives have been shown anticancer and antibacterial activity in addition to be employed as luminescent probes in bioimaging. ${ }^{64}$ The corresponding alkynyl chromone gold(I) 56a-b and the alkynyl flavone gold $\mathbf{5 7}$ derivatives exhibited similar antiproliferative effects than that of auronafin against HepG2 hepatocellular carcinoma, MCF-7 estrogen-responsive breast cancer cells, MDA-MB-231 estrogen-unresponsive breast cancer cells and CCRF-CEM hematological T-lymphoblast-like cancer cells via TrxR inhibition, caspase- 9 and caspase- 3 activations, cell cycle disturbance and DNA damaging activity. Flavonoids complexes $\mathbf{5 5} \mathbf{a}$ and $\mathbf{5 5} \mathbf{b}$ improved the cytotoxic effects on PC-3 human prostate cancer cells in comparison to the flavones and the propargyl ether flavone precursors. However, only moderate $\mathrm{IC}_{50}$ values were obtained and similar to those found with the precursor $\left[\mathrm{AuCl}\left(\mathrm{PPh}_{3}\right)\right]{ }^{63}$

Functionalization of 1,8-naphthalimide chromophores in 4-position and posterior coordination to the $\mathrm{AuPPh}_{3}$ moiety via a terminal propargyl donor provided a family of luminescent gold(I) derivatives (59a-g, Fig. 6). ${ }^{65}$ 
The evaluation of their antiproliferative effects on several cancerous cells (MCF7 breast adenocarcinoma, A549 lung adenocarcinoma, PC3 prostate adenocarcinoma, LOVO colon adenocarcinoma) and HEK (human embryonic kidney) cell line established that all derivatives were more toxic to HEK cells than to the cancer cell lines. However, the most active ones against cancer cells were complexes displaying the glycol appended substituent amine $\mathbf{5 9 b}$ and $59 \mathbf{c}\left(\mathrm{IC}_{50}\right.$ values ranging from 5.1 to $\left.51.9 \mu \mathrm{M}\right)$. Uptake studies into HEK cells and the protistan fish parasite Spironucleus vortens by confocal fluorescence microscopy showed propensity for the localization of the most liphophilic derivatives in mitochondria (in HEK cells) and in hydrogenosomes in Spironucleus vortens.

Heterometallic $\mathrm{Au}-\mathrm{Re}$ complexes have been described as excellent partners in cell imaging and cancer therapy. ${ }^{66}$ Thus, the luminescent rhenium derivative $f a c-\left[\operatorname{Re}(\text { bipy })(\mathrm{CO})_{3} \mathrm{~L}\right]^{+}$with $\mathrm{L}$ alkynyl-imidazole or alkynylpyridine afforded dinuclear complexes 60a-c (Fig. 6) after coordination of the $\mathrm{AuPPh}_{3}$ unit to the alkyne. Higher cytotoxicity was exerted by the heterometallic derivatives toward A549 lung carcinoma cells, in comparison with the mononuclear rhenium precursors $\left(\mathrm{IC}_{50}\right.$ values $>10$ times lower). Confocal fluorescent images revealed a concentration dependent localization pattern, since incubation of cancer cells with the complexes at concentration below their $\mathrm{IC}_{50}$ values showed a similar pattern to that of monometallic species, concordant with cytoplasm localization. However, higher loading concentration up to $150 \mu \mathrm{M}$ prompted higher complex internalization than the monometallic analogs leading to accumulation in a specific organelle in the nucleus.

\subsection{Alkynyl carbene gold derivatives}

Although $N$-heterocyclic carbene derivatives have been widely studied as anticancer agents, ${ }^{40,67-70}$ only one example of mixed NHC-alkynyl complex (61, Fig. 7) with antiproliferative activity has been described so far. ${ }^{71}$ Complex 61 displayed similar activity than cisplatin toward the two different cancer cell lines HCT116 colorectal carcinoma (p53 wild-type and p53 null variant), MCF7 breast adenocarcinoma and A375 malignant melanoma. The lack of selectivity observed for both HCT116 cell lines points to a mechanism independent of p53 activity. Complex 61 evidenced low toxicity in an ex vivo model in healthy rat tissue using the PCKS technology. Thus, a $\mathrm{TC}_{50}$ (toxic concentration) value greater than $50 \mu \mathrm{M}$ was measured for the mixed carbene-alkynyl derivative after its incubation with kidney 


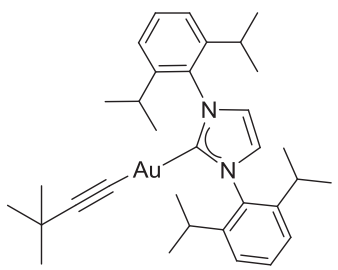

61

Fig. 7 Mixed NHC-alkynyl derivative.

slices, conversely to the observed for cisplatin and auranofin. Moreover, non-significant morphological changes relative to controls were detected in the treated organs.

\section{Platinum alkynyl derivatives}

Cisplatin is the main metal-based drug used in cancer therapy. ${ }^{72}$ Its effectiveness has been proven in a great variety of tumors including ovarian, testicular, head and neck, breast, prostate and lung cancer, which boosted the development of a second generation of platinum drugs. ${ }^{73}$ However, the vast amount of work was devoted to the development of analogous species that mimic the coordination nature of the cisplatin, leaving organometallic complexes relegated to a second position. ${ }^{74}$ Alternatively, organometallic platinum complexes and in particular alkynyl derivatives have lately demonstrated their capacity as anticancer agents, with excellent $\mathrm{IC}_{50}$ values and in some cases exceeding that of cisplatin.

\subsection{Glycosylated alkynyl platinum complexes with terpyridine ligands}

Glycosylated alkynyl platinum derivatives bearing terpyridine ligands were the first examples reported in the literature where the antitumoral activity of an akynyl platinum complex was tested. Che and coworkers pioneered this investigation in 2005 with the development of a series of terpyridine platinum complexes containing either glycosylated alkynyl (complexes 62-64), glycosylated arylalkynyl (complexes 65-68) or arylalkynyl (69) as ancillary ligands (see Fig. 8). ${ }^{75}$ These systems were appealing due to different factors, (a) they would be able to act as metallointercalators for biomolecules, (b) the strength of the $\mathrm{Pt}-\mathrm{C}$ bond would avoid hydrolysis problems seen for $[\mathrm{Pt}(\text { terpy }) \mathrm{Cl}]^{+}$and, (c) the solvent media dependence of the photoluminescence properties of $[\mathrm{Pt}(\text { terpy })(\mathrm{C} \equiv \mathrm{C}-\mathrm{Ar})]^{+}$and related compounds 

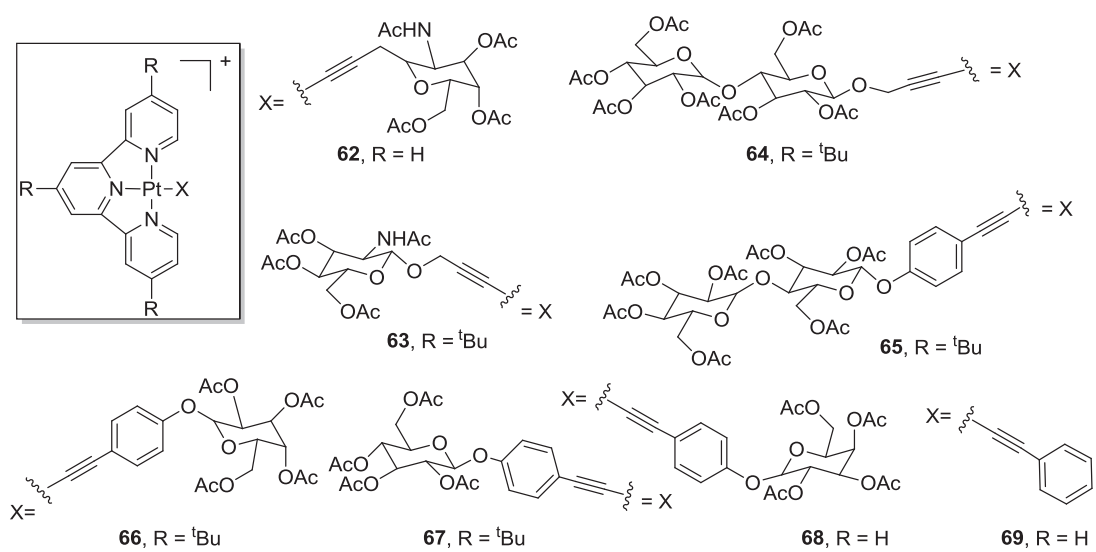

Fig. 8 Terpyridine platinum complexes containing glycosylated acetylide ligands.

could be used for signaling studies of biological interest. Additionally, they suggested that introduction of a glucopyranoside group would promote water solubility as well as specificity toward glycosylated biomolecules. Thus, after analyzing the behavior of these complexes by electrophoresis and UV spectroscopy, it could be concluded that both families, the glycosylated alkynyl and the arylalkynyl derivatives bind to DNA. However, only the arylalkynyl derivatives 65-67 were emissive in aqueous solution indicating that the presence of the aryl moiety was crucial for reaching the emissive behavior. All of them showed high antiproliferative activity against five human carcinoma cell lines (HeLa (cervix), HepG2 (liver), SF-268 (brain), NCI-H460 (lung), MCF-7 (breast)), being those of the glycosylated arylalkynyl derivatives (65-68) the most toxic species $\left(\mathrm{IC}_{50}=0.06-0.2 \mu \mathrm{M}\right)$, around 100 times more cytotoxic than the cisplatin in the same conditions. This study also revealed the importance of avoiding acetylated imine moieties, as complexes $\mathbf{6 2}$ and $\mathbf{6 3}$ were the less active complexes within the five cell lines, with $\mathrm{IC}_{50}$ values ranging from 15 to $28 \mu \mathrm{M}$. Additionally, the glycosylated arylalkynyl system seems to govern the cell death pathway, which was mainly due to an apoptotic process. It was found that $\mathbf{6 7}$ significantly regulated several genes such as C20orf97, PEA15, STK15 and PCNA with roles in cell proliferation and apoptosis, whereas the 68 (lacking of glycosylate pyranosyl) as well as the parent complex [ $\mathrm{Pt}$ (terpy) $\mathrm{Cl}]^{+}$did not show any regulation.

\subsection{Alkynyl platinum complexes with COD ligands}

Alkynyl platinum complexes containing 1,5-cyclooctadiene (COD) ligand instead of terpyridine backbone were investigated as antitumoral agents by 
A. Klein and coworkers in $2010 .^{76}$ Some years earlier it was demonstrated that complexes following the general formula $[\mathrm{Pt}(\mathrm{COD})(\mathrm{Me})(\mathrm{Nuc})] \mathrm{NO}_{3}$ (Nuc: guanosine, cytosine or adenosine nucleosides) retained its preferential binding to guanosine, as the majority of platinum complexes. Additionally, similar species such as $[\mathrm{Pt}(\mathrm{COD})(\mathrm{Me})(\mathrm{Cl})]$ and $[\mathrm{Pt}(\mathrm{COD})(\mathrm{Me})(\mathrm{Cyt})]\left(\mathrm{SbF}_{6}\right)$ exhibited also high toxicity in colon HT-29 and breast MCF-7 carcinoma cells. ${ }^{77}$ Therefore, they intended to elucidate whether the introduction of various electron rich coligands to the platinum COD core could improve the cytotoxic potential. Hence, a series of neutral platinum complexes $[\mathrm{Pt}(\mathrm{COD})(\mathrm{Me})$ (C三C-R)] (Fig. 9), with $R=$ 4-fluorophenyl (70), 4-tolyl (71), 4-nitrophenyl (72) or phenyl (73), were synthesized and their cytotoxic activity analyzed in two different cell lines, colon carcinoma HT-29 and MCF-7 breast adenocarcinoma cells. ${ }^{76}$ The $\mathrm{IC}_{50}$ values found ranged from 0.2 to $10 \mu \mathrm{M}$, being 71 the most cytotoxic species. However, no specific antiproliferative trend was observed. Several years later, a second attempt was made using the same type of COD-Pt core. This time, mono- and dialkynyl platinum-COD derivatives, complexes 74-89, were synthesized and their antiproliferative activity analyzed (Fig. 9), which led to some interesting conclusions regarding the structure-activity relationship (SAR). ${ }^{78}$ In general, the dialkynyl platinum complexes were more cytotoxic than the corresponding methyl substituted ones. The $\mathrm{IC}_{50}$ values were below $0.6 \mu \mathrm{M}$ in every case. It seemed clear that quicker decomposition of the Pt-alkynyl bond, provides better antiproliferative activity. Moreover, the perpendicular orientation of the $\mathrm{C} \equiv \mathrm{C}$-aryl group to the $\mathrm{Pt}$ coordination plane might be also affecting the cytotoxic character. Furthermore, the different methyl substitution on the aromatic ring (orto $(\mathbf{8 2})$, meta $(\mathbf{8 3})$, para $(\mathbf{8 4})$ ) barely affected the antiproliferative behavior. Alternatively, differences were found in the case of the nitro group, being the orto substituted (85) the less active species. Finally these complexes showed inhibition of the enzyme thioredoxin reductase (TrxR), which in addition to DNA, could be also a potential biological target.

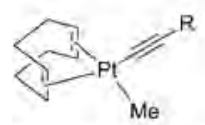

$R=3-$ Tolyl (76),

$R=2-$ Nitrophenyl (77),

$R=3-$ Nitrophenyl $(78)$,

$\mathrm{R}=4$-Metoxyphenyl (79),

$R=2-$ Pyridyl $(80)$

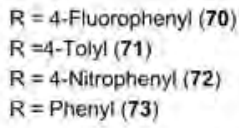

$R=4-$ Fluorophenyl (70)

$\mathrm{R}=4-$ Tolyl (71)

$\mathrm{R}=4-$ Nitrophenyl (72)

$\mathrm{R}=$ Phenyl (73)

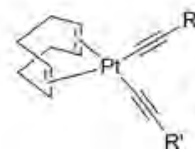

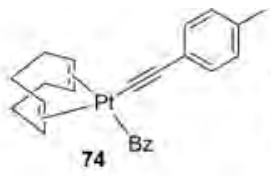

$\mathrm{R}^{\prime}$ = Phenyl $(\mathbf{8 1}), \mathbf{R}^{\prime}=2$-Totyl $(82)$ $R^{\prime}=3$-Tolyl (83), $R^{\prime}=4$-Totyl $(84)$ $\mathrm{R}^{\prime}=2$-Nitrophenyl $(85)$

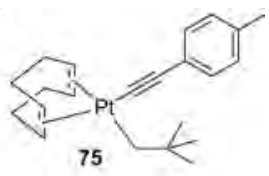

$\mathrm{R}^{\prime}=$ 3-Nitrophenyl (86)

$\mathrm{R}^{\prime}=4-$ Meloxymethyl $(87)$ $\mathrm{R}^{\prime}=4$-Fluorophenyl $(88)$ $\mathrm{R}^{\prime}=$ 2-Pyridyl (89)

Fig. 9 Alkynyl platinum complexes containing COD. 

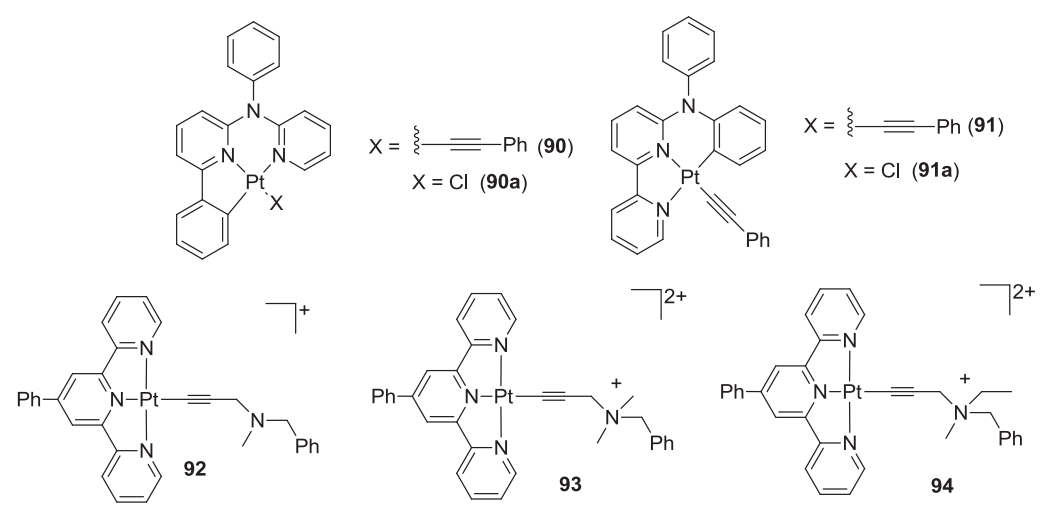

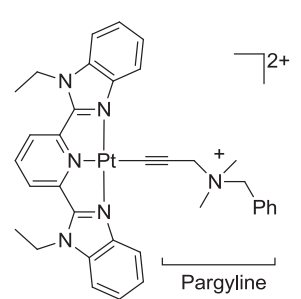

95
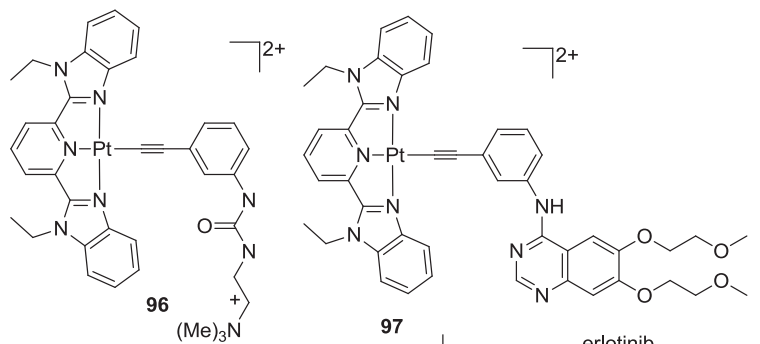

97

erlotinib

Fig. 10 Tridentate $\mathrm{C}^{\wedge} \mathrm{N}^{\wedge} \mathrm{N}$, Terpy and $\mathrm{Et}_{2}$ bzimpy alkynyl platinum(II) complexes.

\subsection{Alkynyl platinum complexes with planar polyaromatic ligands}

Cyclometalated platinum alkynyl complexes containing tridentate $\mathrm{C}^{\wedge} \mathrm{N}^{\wedge} \mathrm{N}$ ligands (Fig. 10), were investigated by Chen, Huo and coworkers. ${ }^{79}$ Organometallic platinum species containing either tridentate $\mathrm{C}^{\wedge} \mathrm{N}^{\wedge} \mathrm{N}$ or $\mathrm{N}^{\wedge} \mathrm{C}^{\wedge} \mathrm{N}$ coordinating ligands have been far less investigated, possibly because the focus has been always on cisplatin analogs as previously commented. ${ }^{80}$ However, these types of scaffolds when incorporated to platinum metal were found to afford anticancer activity by inhibiting the expression of survivin (a novel inhibitor of apoptosis protein, IAP), activating poly(ADPribose)polymerase (PARP) and inducing apoptosis. ${ }^{81}$ Moreover, in general they have rich photophysical properties that allows the use of fluorescence techniques, for assessing their biodistribution. ${ }^{82}$ Consequently, they are potential candidates for novel trackable anticancer agents. Examination of different $\mathrm{C}^{\wedge} \mathrm{N}^{\wedge} \mathrm{N}$-ortometallated platinum complexes containing alkynyl (90 and 91 ) or chloride (90a and 91 a) units as ancillary ligands revealed that the presence of the labile chloride was critical. ${ }^{79}$ None of the alkynyl derivatives (90 and $\mathbf{9 1}$ ) showed significant cytotoxicity in lung cancer NCI-H522 
cells ( $\mathrm{IC}_{50}>162 \mu \mathrm{M}$ for both of them). It can be then hypothesized that for this type of species, dissociation of $\mathrm{Pt}-\mathrm{Cl}$ bond may be indispensable for cytotoxicity.

Additionally, platinum(II) complexes containing planar polyaromatic ligands have shown to be selective G-quadruplex binders. ${ }^{83,84}$ G-quadruplexes are involved in the regulation of telomerase activity, a ribonucleoprotein that is activated in $80-90 \%$ of human tumors and can serve as specific tumor-selective targets for chemotherapy. ${ }^{85}$ Therefore developing good G-quadruplex stabilizers may show antitumor effects against a wide range of cancer cells. The judicious choice of auxiliary ligands as well as increasing the $\pi$ surface on the complexes leads to an increase in binding affinity and selectivity for $G$ quadruplex over duplex DNA. ${ }^{86}$ Gao and coworkers have explored such possibility with alkynylplatinum derivatives containing either 4-(4-methylphenyl)-2, $2^{\prime}: 6^{\prime}, 2^{\prime \prime}$ terpyridine (terpy) $\left(\mathbf{9 2 - 9 4}\right.$, Fig. 10) ${ }^{87,88}$ or 2, 6-bis $\left(N\right.$-ethylbenzimidazole- $2^{\prime}-$ yl)pyridine (Et $t_{2}$ bzimpy), (95-97, Fig. 10) as the polydentate ligand. ${ }^{89}$ The $\sigma$-alkynyl ancillary ligands chosen were either pargyline, peralkylated ammonium derivatives or erlotinib, which is a first-line treatment in patients with non-small cell lung cancer (NSCLC). Analysis of the cytotoxic activity in lung adenocarcinoma A549 cells revealed that terpy derivatives were more cytotoxic $\left(\mathrm{IC}_{50} c a .1 \mu \mathrm{M}\right)$ than the $\mathrm{Et}_{2}$ bzimpy analogous $\left(\mathrm{IC}_{50} c a .8 \mu \mathrm{M}\right)$. Regarding the alkynyl ligand, the quaternary ammonium alkynyl complex 94 had the best behavior within the family of terpy derivatives $\left(\mathrm{IC}_{50}(\mathbf{9 4})=0.42 \pm 0.1 \mu \mathrm{M}\right)$, whereas the erlotinib derivative, complex 97 was the most cytotoxic within the $\mathrm{Et}_{2}$ bzimpy scaffold $\left(\mathrm{IC}_{50}(\mathbf{9 7})=6.69 \mu \mathrm{M}\right)$. It is worth noting that complexes 92-94 were also tested in leukemia (K562) and gastric carcinoma (SGC7901) cells delivering very promising $\mathrm{IC}_{50}$ values $\left(\mathrm{IC}_{50}=3.28-8.79 \mu \mathrm{M}\right)$. However, their selectivity toward tumor cells was low as the cytotoxicity value for HEK293 cells (non-cancerous cells) was also elevated. Additionally, studies performed by UV-vis absorption spectroscopy, circular dichroism and molecular docking studies showed that complexes 92-94 associate with telomeric and c-myc G-quadruplexes via groove binding-electrostatic interactions. Further analysis under crowded conditions (in presence of $40 \mathrm{wt} \%$ PEG 200) revealed that complex $\mathbf{9 4}$ is the only one that retained high affinity an selectivity toward c-myc oncogene. ${ }^{83}$ Alternatively, complexes 95-97 also displayed high affinities for G-quadruplex, being those containing a phenyl acetylene moiety (complexes $\mathbf{9 6}$ and $\mathbf{9 7}$ ), the ones that induce a higher degree of c-myc G-quadruplex stabilization. These data stress the importance of the structure of the alkynyl ligand within the interaction of $\mathrm{Pt}(\mathrm{II})$ and G-quadruplexes. 


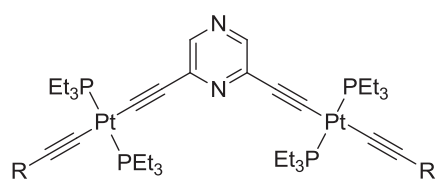

98-102

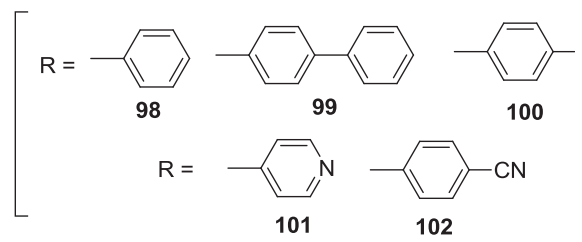

Fig. 11 Polynuclear platinum alkynyl complexes.

\subsection{Dinuclear alkynyl platinum complexes}

Dinuclear alkynyl platinum complexes were also investigated as anticancer agents to widen the spectrum of platinum based drugs. Das and coworkers reported the first pyrazine based dialkynyl platinum derivatives that have been tested an anticancer agents. ${ }^{90}$ Thus, a pyrazine ring was used as a bridge ligand between two platinum phosphane alkynyl unis at C2 and C6 positions. Then, each platinum center was covalently linked to an aromatic or heteroaromatic alkynyl derivative and two triethylphosphane ligands, affording robust complexes (98-102, see Fig. 11). Analysis of their antiproliferative activity against lung cancer A549 cells revealed that only complex 101, bearing a pendant pyridine, had a similar $\mathrm{IC}_{50}$ value to that of cisplatin $\left(\mathrm{IC}_{50}=3-5 \mu \mathrm{M}\right)$. The other diplatinated species showed $\mathrm{IC}_{50}$ values ranging from 10 to $30 \mu \mathrm{M}$. Contrary to cisplatin that is able to undergo hydrolysis in saline water to afford the reactive intermediate aqua complex, cis- $\left[\mathrm{PtCl}\left(\mathrm{NH}_{3}\right)_{2}\left(\mathrm{H}_{2} \mathrm{O}\right)\right]^{+}$, with subsequent interaction with the purine/pyrimidine bases of DNA, complexes 98-102 are robust in those conditions. Hence, the cytotoxic behavior of these species would be associated to a mechanism different of cisplatin, opening the door to additional biological targets.

\subsection{Alkynyl platinum complexes as photosensitizers (PSs)}

Alternatively, alkynyl platinum derivatives can be also considered as potential photosensitizers (PSs) for photodynamic therapy (PDT). In 2014, Kondaiah and Chakravarty examined for the first time such possibility using a terpyridine $\mathrm{Pt}(\mathrm{II})$ derivative functionalized with a ferrocenyl group to reduce the undesired toxicity in absence of light. ${ }^{91}$ It was expected that the ferrocenyl group would reduce the overall planarity limiting its intercalating DNA ability as well as increasing its lipophilicity leading to a higher biocompatibility. In fact, complex 103 with a propargyl carbazole as the ancillary ligand showed a very promising behavior as photosensitizer (Fig. 12). Immortalized human skin keratinocytes (HaCaT cells) and 

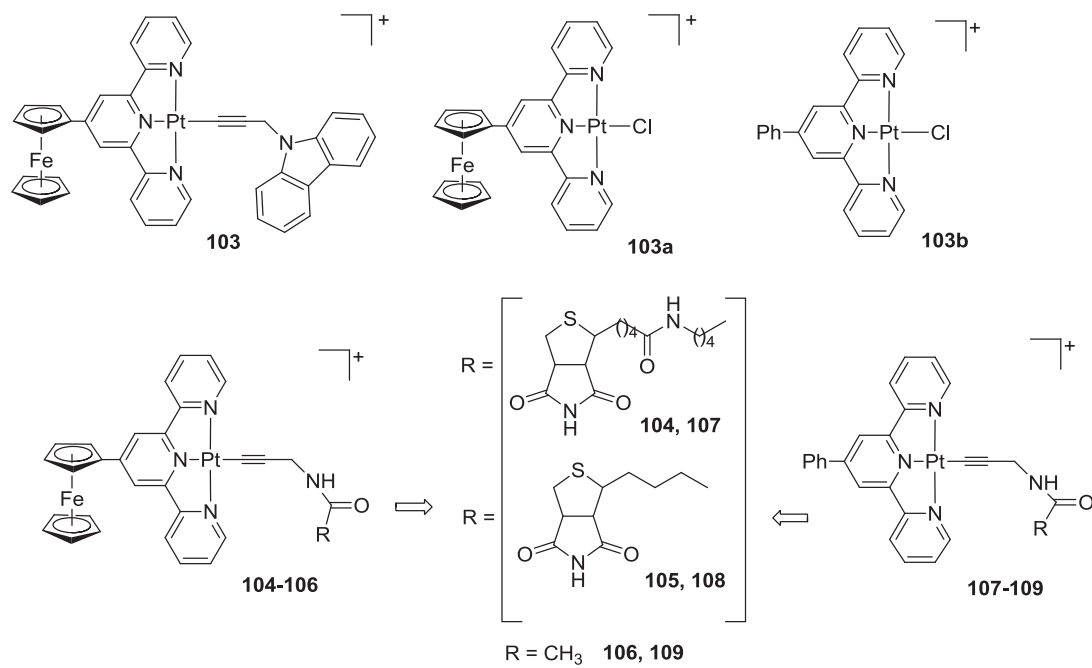

Fig. 12 Photoactive platinum(II) complexes.

MCF-7 were treated with 103 in presence and absence of light. In both cell lines the cytotoxicity of the probe increased up to eight times upon irradiation $\left(\mathrm{IC}_{50}(\right.$ dark $) \approx 85 \mu \mathrm{M} v s \mathrm{IC}_{50}($ light $\left.) \approx 10 \mu \mathrm{M}\right)$. The presence of the alkynyl ligand did not seen decisive for the light-induced toxicity as chloride analogous $(\mathbf{1 0 3 a})$ showed similar $\mathrm{IC}_{50}$ values $\left(\mathrm{IC}_{50}(\right.$ dark $) \approx 70 \mu \mathrm{M}$ vs $\mathrm{IC}_{50}($ light $\left.) \approx 12 \mu \mathrm{M}\right)$. In contrast, the photo-activity was mainly attributed to the ferrocene moiety, which could generate reactive ferrocenenium ion that effectively activated molecular oxygen. ${ }^{92}$ Analogous Pt(II) complex lacking of the ferrocenyl moiety, complex 103b, did not present a good viability as PS. In particular, complex $\mathbf{1 0 3}$ in presence of light showed a moderate increment of the sub-G1/G0 population suggesting cell death leading to fragmented DNA. Annexin V-FITC/PI assay indicated that early apoptosis was the cell death mechanism mode. This result was further corroborated by electrophoresis performing DNA ladder formation assay. As expected, external binding to calf thymus DNA was observed instead of intercalation, driven by the presence of the ferrocenyl moiety. In view of the promising results with ferrocenylterpyridine platinum alkynyl derivatives, further complexes (104-106, Fig. 12) have been reported for targeted photo-induced cytotoxicity. ${ }^{93}$ In this occasion a biotinylated alkynyl was used as ancillary ligand in order to target specifically cancer cells. Biotinylated derivatives are known to display cancer cell-specific uptake. ${ }^{94,95}$ In addition, phenylterpyridine analogous were also described, 107-109, 
to understand the role of a metal-bound Fc-terpy ligand over Ph-terpy as photoiniciator. The antiproliferative activity assay in breast carcinoma cells BT474 and human normal breast epithelial cells HBL-100 revealed that the biotinylated photoactive Fc-Terpy complexes 104-106 showed considerably higher phoinduced cytotoxicity $\left(\mathrm{IC}_{50}(\right.$ dark $)>50 \mu \mathrm{M} v s \mathrm{IC}_{50}($ light $) \approx$ $12 \mu \mathrm{M})$ with a selective uptake by cancer cells, whereas the free ligand Fc-terpy was inactive in all cases. In contrast, $\mathrm{pH}$-terpy species (107-109) displayed similar $\mathrm{IC}_{50}$ values in presence and absence of light $\left(\mathrm{IC}_{50}(\mathrm{BT} 474) \approx 15 \mu \mathrm{M}\right.$ and $\left.\mathrm{IC}_{50}(\mathrm{HBL}-100) \approx 27 \mu \mathrm{M}\right)$, which revealed the importance of the ferrocenyl moitety to minimize the undesired toxicity in absence of light. Additional examination of ROS production by dichlorofluorescein diacetate (DCFH-DA) assay showed that Fc-Terpy derivatives generated ROS within the cells only upon photoexposure to light of 400-700 nm, whereas Ph-Terpy showed ROS generation both in dark and light conditions. Moreover, annexin V-FICT/PI assay indicated that cell death was due to an early apoptosis mechanism in all cases and the cell cycle profiling assay revealed that complexes 104-106 performed a substantial sub-G1 arrest only upon irradiation. These results contrasted with that obtained for the species lacking of Fc groups (107-109) as none of them showed a significant difference between dark and photoexposure conditions, making them inappropriate for photodynamic therapy. Further DNA binding and cleavage studies emphasized the lack of DNA intercalation for 104-106 which was observed in the case of complexes 107-109 driving by the absence of the Fc unit. Alternatively, complexes 104-106 were found to release the biotinylated ligands in red light $(647 \mathrm{~nm})$, which is believed to photoiniciate a covalent DNA binding by the active platinum species. Therefore, it could be concluded that the high toxicity attributed to the Fc-terpy species could be derived from a synergistic cytotoxic effect, the photorelease of active platinum species and the generation of ROS.

\subsection{Dual alkynyl platinum-based photosensitizers and photoimaging agents}

In recent years, $\mathrm{Pt}(\mathrm{II})$-based photosensitizers (PSs) for photodynamic therapy with photoimaging properties have been reported to get insight of the drug biodistribution in vivo and reveal their possible therapeutic mechanisms. Within this context, near-infrared (NIR) PSs are of particular importance as this wavelength range is known as the therapeutic window $(700-850 \mathrm{~nm})$, i.e., the light possesses a deeper tissue penetration and it can reach effectively bigger and inner tumors. Chakravarty and coworkers 


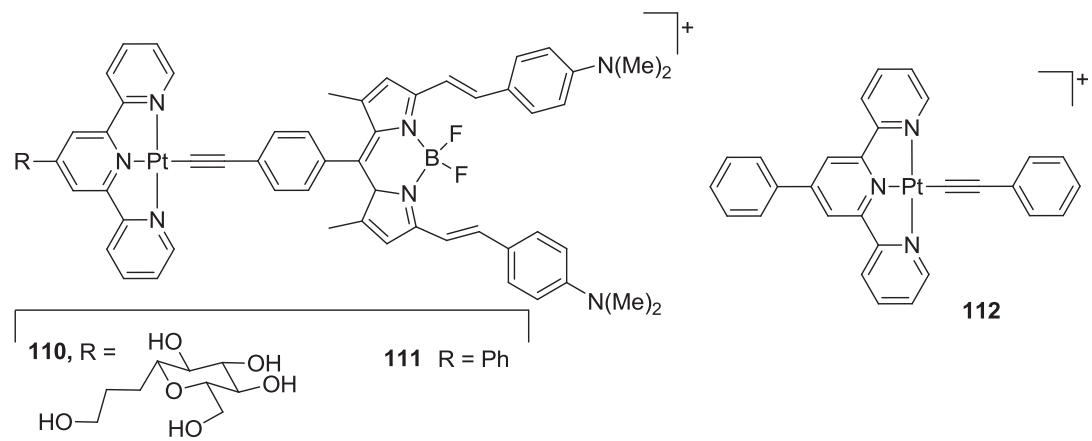

Fig. 13 Mono- and polynuclear alkynyl platinum complexes.

have envisaged a terpyridine alkynyl Pt derivative in which they have incorporated a BODIPY derivative (4,4-Difluoro-5,7-dimethyl-4-bora-3a,4adiaza-s-indacene) for combining both, the photosensitizing and bioimaging properties. Additionally, a glucose moiety was introduced in order to explore the possibility of rendering greater selectivity toward cancer cells, see compound 110 in Fig. 13. ${ }^{96}$ BODIPY is well-known for its versatile photosensitizing and photophysical ${ }^{97}$ properties and it has been previously reported to be localized in the mitochondria of cancer cells. ${ }^{98}$ Additionally, the use of an appending glucose to look for specific targeting is a common strategy to confer selectivity as many tumors have the glucose transporter GLUT-1 overexpressed. ${ }^{99}$ In the present case, the photoinduced anticancer activity of 110 and its analogous complex lacking of the appended glucose moiety, complex 111, as well as the parent complex lacking also of BODIPY, complex 112, was investigated against HeLa, MCF-7 and A549 cells in dark and under red light $(\lambda=600-720 \mathrm{~nm})$. The experiment showed the crucial role of the BODIPY moiety as complex 112 displayed $\mathrm{IC}_{50}$ values over $100 \mu \mathrm{M}$ for the three cell lines in dark and upon radiation. In contrast, complexes 110 and 111 showed high photocytotoxic activity with $\mathrm{IC}_{50}$ values ranging from 2.3 to $6.0 \mu \mathrm{M}$ and from 13.3 to $24.7 \mu \mathrm{M}$ under irradiation respectively, and over $91.4 \mu \mathrm{M}$ in every case in dark conditions. Titration experiments with 1,3-diphenylisobenzofuran (DPBF) indicated that 110 and 111 generated singlet oxygen $\left({ }^{1} \mathrm{O}_{2}\right)$ in red light with a singlet oxygen quantum yield $(\Phi \Delta)$ value of $c a .0 .6$, indicating their photosensitizing ability. In addition, mass spectroscopy and ${ }^{1} \mathrm{H}$ NMR revealed that the alkynyl-BODIPY ligand was also released upon red light irradiation. The fact that complex 110 accomplished better results as PSs agent than $\mathbf{1 1 1}$ suggested its superior capacity to permeate the cells, possibly due to the presence of the appendant glucose which facilitates its internalization as well as 
enhance the drug aqueous solubility. To further probe this statement, cellular uptake and selectivity studies were performed by flow cytometry using normal HPL1D and cancer cells (A549). This experiment probed that complex 110 accumulated preferentially in cancer cell than in normal cells and that its cell permeability was higher than that of $\mathbf{1 1 1}$, emphasizing the role of the appendant glucose. Finally, fluorescence microscopy demonstrated their preferential accumulation in the mitochondria over the nucleus, which is a great input in the development of photodynamic therapy agents. ${ }^{100}$

\section{Conclusions}

In conclusion, it is clear that metal alkynyl complexes have many opportunities to offer in the development of new metal-based chemotherapeutic agents, especially for gold and platinum derivatives, whose complexes present a great stability due to the $\mathrm{M}-\mathrm{C} \equiv \mathrm{CR}$ bonds. This is a key feature in drug synthesis because prevents dissociation of the metal species in biological media before reaching the target with the consequence deactivation and toxicity. Many examples of gold derivatives with alkynyl ligands have been reported, and in most of the cases with the general formula $\left[\mathrm{Au}(\mathrm{C} \equiv \mathrm{CR}) \mathrm{PR}_{3}^{\prime}\right]$, and the structure-activity studies have been centered in changing the substituents in the alkynyl or in the phosphane ligand. In general, all the compounds exhibited an excellent cytotoxic activity in different cancer cell lines but did not show big differences among them to conclude any structure-activity relationship. Probably, more differences have been found in the main biological target. Thioredoxin reductase has been revealed as the main target, for which complexes with strong donating substituents displayed high inhibition efficacy. A cooperative effect was observed in polynuclear or heteronuclear complexes leading to an increase in the biological activity compared to their mononuclear precursors was found. Many gold derivatives with a propargyl-substituted fluorophores have been described and because of their interesting photophysical properties, biodistribution studies were performed in order to obtain information about the cellular uptake and potential biological targets. Alkynyl platinum complexes with antitumor properties have been described, and they include different ligand scaffolds such as COD, tridententate $\mathrm{N}$-based or cyclometallated ligands. These compounds, although in general less active than cisplatin, do not easy dissociate the ligands and, consequently, their cytotoxic effect can be associated to a different mechanism to that of cisplatin, opening the door to additional biological targets. Furthermore, these 
compounds are promising candidates to be used as photosensitizers in photodynamic therapy with easily tuneable photophysical properties. Substitution with vectors for specific targeting are encouraging factors for further development of better and more effective agents in photodynamic therapy and cell imaging.

\section{Acknowledgments}

Authors thank the Ministerio de Ciencia, Innovación y Universidades (CTQ201675816-C2-1-P) and Gobierno de Aragón-Fondo Social Europeo (E07_17R) for financial support.

\section{References}

1. Long NJ, Williams CK. Metal alkynyl sigma complexes: synthesis and materials. Angew Chem Int Ed. 2003;42:2586-2617.

2. Paul F, Lapinte C. Organometallic molecular wires and other nanoscale-sized devices. an approach using the organoiron (dppe) Cp*Fe building block. Coord Chem Rev. 1998;178:431-509.

3. Barlow S, Ohare D. Metal-metal interactions in linked metallocenes. Chem Rev. 1997;97:637-669.

4. Whittall IR, McDonagh AM, Humphrey MG, Samoc M. Organometallic complexes in nonlinear optics I: second-order nonlinearities. In: Stone FGA, West R, eds. Advances in Organometallic Chemistry. 1998:291-362.

5. Yam VWW. Molecular design of transition metal alkynyl complexes as building blocks for luminescent metal-based materials: structural and photophysical aspects. Acc Chem Res. 2002;35:555-563.

6. Bruce DW, O'Hare D. Inorganic Materials. 2nd ed. Chichester: Wiley; 1996.

7. Gupta AK, Orthaber A. Alkynyl coinage metal clusters and complexes-syntheses, structures, and strategies. Chem - Eur J. 2018;24:7536-7559.

8. Blanco MC, Camara J, Gimeno MC, et al. Synthesis of gold-silver luminescent honeycomb aggregates by both solvent-based and solvent-free methods. Angew Chem Int Ed. 2012;51:9777-9779.

9. Koshevoy IO, Karttunen AJ, Shakirova JR, et al. Halide-directed assembly of multicomponent systems: highly ordered Au-I-Ag-I molecular aggregates. Angew Chem Int Ed. 2010;49:8864-8866.

10. Touchard D, Dixneuf PH. A new class of carbon-rich organometallics. The C-3, C-4 and C-5 metallacumulenes $\mathrm{Ru}=(\mathrm{C}=)_{(\mathrm{n})} \mathrm{CR}_{2}$. Coord Chem Rev. 1998;178-180: 409-429.

11. Bruce MI. Transition metal complexes containing allenylidene, cumulenylidene, and related ligands. Chem Rev. 1998;98:2797-2858.

12. Halliday CJV, Lynam JM. Gold-alkynyls in catalysis: alkyne activation, gold cumulenes and nuclearity. Dalton Trans. 2016;45:12611-12626.

13. Nast R. Coordination chemistry of metal alkynyl compounds. Coord Chem Rev. 1982;47:89-124.

14. Manna J, John KD, Hopkins MD. The bonding of metal-Alkynyl complexes. Adv Organomet Chem. 1995;38:79-154.

15. Wang XY, Guo ZJ. Targeting and delivery of platinum-based anticancer drugs. Chem Soc Rev. 2013;42:202-224. 
16. Muhammad N, Guo ZJ. Metal-based anticancer chemotherapeutic agents. Curr Opin Chem Biol. 2014;19:144-153.

17. Zhang PY, Sadler PJ. Redox-active metal complexes for anticancer therapy. Eur J Inorg Chem. 2017;1541-1548.

18. Bertrand B, Casini A. A golden future in medicinal inorganic chemistry: the promise of anticancer gold organometallic compounds. Dalton Trans. 2014;43:4209-4219.

19. Zou TT, Lum CT, Lok CN, Zhang JJ, Che CM. Chemical biology of anticancer gold(III) and gold(I) complexes. Chem Soc Rev. 2015;44:8786-8801.

20. Ott I, Qian XH, Xu YF, et al. A gold(I) phosphine complex containing a Naphthalimide ligand functions as a TrxR inhibiting antiproliferative agent and angiogenesis inhibitor. J Med Chem. 2009;52:763-770.

21. Gutierrez A, Gracia-Fleta L, Marzo I, Cativiela C, Laguna A, Gimeno MC. Gold (I) thiolates containing amino acid moieties. Cytotoxicity and structure-activity relationship studies. Dalton Trans. 2014;43:17054-17066.

22. Ronconi L, Giovagnini L, Marzano C, et al. Gold dithiocarbamate derivatives as potential antineoplastic agents: design, spectroscopic properties, and in vitro antitumor activity. Inorg Chem. 2005;44:1867-1881.

23. Quero J, Cabello S, Fuertes T, et al. Proteasome versus Thioredoxin reductase competition as possible biological targets in antitumor mixed thiolate-dithiocarbamate gold(III) complexes. Inorg Chem. 2018;57:10832-10845.

24. Yan K, Lok CN, Bierla K, Che CM. Gold(I) complex of N,N '-disubstituted cyclic thiourea with in vitro and in vivo anticancer properties-potent tight-binding inhibition of thioredoxin reductase. Chem Commun. 2010;46:7691-7693.

25. Berners-Price SJ, Bowen RJ, Galettis P, Healy PC, McKeage MJ. Structural and solution chemistry of gold(I) and silver(I) complexes of bidentate pyridyl phosphines: selective antitumour agents. Coord Chem Rev. 1999;185-6:823-836.

26. Urig S, Fritz-Wolf K, Reau R, et al. Undressing of phosphine gold(I) complexes as irreversible inhibitors of human disulfide reductases. Angew Chem Int Ed. 2006;45:1881-1886.

27. Baker MV, Barnard PJ, Berners-Price SJ, et al. Cationic, linear Au(I) N-heterocyclic carbene complexes: synthesis, structure and anti-mitochondrial activity. Dalton Trans. 2006;3708-3715.

28. Johnson A, Marzo I, Gimeno MC. Ylide ligands as building blocks for bioactive group 11 metal complexes. Chem - Eur J. 2018;24:11693-11702.

29. Marcon G, Carotti S, Coronnello M, et al. Gold(III) complexes with bipyridyl ligands: solution chemistry, cytotoxicity, and DNA binding properties. J Med Chem. 2002;45:1672-1677.

30. Barnard PJ, Berners-Price SJ. Targeting the mitochondrial cell death pathway with gold compounds. Coord Chem Rev. 2007;251:1889-1902.

31. Nobili S, Mini E, Landini I, Gabbiani C, Casini A, Messori L. Gold compounds as anticancer agents: chemistry, cellular pharmacology, and preclinical studies. Med Res Rev. 2010;30:550-580.

32. Liu HT, Xiong XG, Dau PD, et al. Probing the nature of gold-carbon bonding in gold-alkynyl complexes. Nat Commun. 2013;4:2223. https://doi.org/10.1038/ ncomms 3223 .

33. Chui CH, Wong RSM, Gambari R, et al. Antitumor activity of diethynylfluorene derivatives of gold(I). Bioorg Med Chem. 2009;17:7872-7877.

34. Schuh E, Valiahdi SM, Jakupec MA, Keppler BK, Chiba P, Mohr F. Synthesis and biological studies of some gold(I) complexes containing functionalised alkynes. Dalton Trans. 2009;10841-10845.

35. Meyer A, Bagowski CP, Kokoschka M, et al. On the biological properties of alkynyl phosphine gold(I) complexes. Angew Chem Int Ed Engl. 2012;51:8895-8899. 
36. Medici S, Peana M, Nurchi VM, Lachowicz JI, Crisponi G, Zoroddu MA. Noble metals in medicine: latest advances. Coord Chem Rev. 2015;284:329-350.

37. Nardon C, Boscutti G, Fregona D. Beyond platinums: gold complexes as anticancer agents. Anticancer Res. 2014;34:487-492.

38. Komeda S, Casini A. Next-generation anticancer Metallodrugs. Curr Top Med Chem. 2012;12:219-235.

39. Casini A, Messori L. Molecular mechanisms and proposed targets for selected anticancer gold compounds. Curr Top Med Chem. 2011;11:2647-2660.

40. Ott I. On the medicinal chemistry of gold complexes as anticancer drugs. Coord Chem Rev. 2009;253:1670-1681.

41. McKeage MJ, Maharaj L, Berners-Price SJ. Mechanisms of cytotoxicity and antitumor activity of gold(I) phosphine complexes: the possible role of mitochondria. Coord Chem Rev. 2002;232:127-135.

42. Andermark V, Goke K, Kokoschka M, et al. Alkynyl gold(I) phosphane complexes: evaluation of structure-activity-relationships for the phosphane ligands, effects on key signaling proteins and preliminary in-vivo studies with a nanoformulated complex. J Inorg Biochem. 2016;160:140-148.

43. De Nisi A, Bergamini C, Leonzio M, et al. Synthesis, cytotoxicity and anti-cancer activity of new alkynyl-gold(I) complexes. Dalton Trans. 2016;45:1546-1553.

44. Zhang D, Xu Z, Yuan J, et al. Synthesis and molecular recognition studies on small-molecule inhibitors for Thioredoxin reductase. J Med Chem. 2014;57:8132-8139.

45. Vergara E, Cerrada E, Casini A, Zava O, Laguna M, Dyson PJ. Antiproliferative activity of gold(I) alkyne complexes containing water-soluble Phosphane ligands. Organometallics. 2010;29:2596-2603.

46. Sanchez-de-Diego C, Marmol I, Perez R, Gascon S, Rodriguez-Yoldi MJ, Cerrada E. The anticancer effect related to disturbances in redox balance on Caco-2 cells caused by an alkynyl gold(I) complex. J Inorg Biochem. 2017;166:108-121.

47. Liévin-Le Moal V, Servin AL. Pathogenesis of human Enterovirulent Bacteria: lessons from cultured, fully differentiated human Colon Cancer cell lines. Microbiol Mol Biol Rev. 2013;77:380-439.

48. Marmol I, Virumbrales-Munoz M, Quero J, et al. Alkynyl gold(I) complex triggers necroptosis via ROS generation in colorectal carcinoma cells. J Inorg Biochem. 2017; 176:123-133.

49. Arcau J, Andermark V, Aguilo E, et al. Luminescent alkynyl-gold(I) coumarin derivatives and their biological activity. Dalton Trans. 2014;43:4426-4436.

50. Gavara R, Aguilo E, Schur J, Llorca J, Ott I, Rodriguez L. Study of the effect of the chromophore and nuclearity on the aggregation and potential biological activity of gold(I) alkynyl complexes. Inorg Chim Acta. 2016;446:189-197.

51. Garcia-Moreno E, Gascon S, Rodriguez-Yoldi MJ, Cerrada E, Laguna M. S-Propargylthiopyridine Phosphane derivatives as anticancer agents: characterization and antitumor activity. Organometallics. 2013;32:3710-3720.

52. Garcia-Moreno E, Tomas A, Atrian-Blasco E, et al. In vitro and in vivo evaluation of organometallic gold(I) derivatives as anticancer agents. Dalton Trans. 2016;45:2462-2475.

53. Wenzel M, Bertrand B, Eymin MJ, et al. Multinuclear cytotoxic Metallodrugs: physicochemical characterization and biological properties of novel heteronuclear gold-titanium complexes. Inorg Chem. 2011;50:9472-9480.

54. Pelletier F, Comte V, Massard A, et al. Development of bimetallic Titanoceneruthenium-arene complexes as anticancer agents: relationships between structural and biological properties. J Med Chem. 2010;53:6923-6933.

55. Gonzalez-Pantoja JF, Stern M, Jarzecki AA, et al. Titanocene-phosphine derivatives as precursors to cytotoxic Heterometallic TiAu2 and TiM $(\mathrm{M}=\mathrm{Pd}, \mathrm{Pt})$ compounds. Studies of their interactions with DNA. Inorg Chem. 2011;50:11099-11110. 
56. Wenzel M, Bigaeva E, Richard P, et al. New heteronuclear gold(I)-platinum(II) complexes with cytotoxic properties: are two metals better than one? I Inorg Biochem. 2014;141:10-16.

57. Fernandez-Gallardo J, Elie BT, Sanau M, Contel M. Versatile synthesis of cationic $\mathrm{N}$-heterocyclic carbene-gold(I) complexes containing a second ancillary ligand. Design of heterobimetallic ruthenium-gold anticancer agents. Chem Commun. 2016;52: 3155-3158.

58. Elie BT, Pechenyy Y, Uddin F, Contel M. A heterometallic ruthenium-gold complex displays antiproliferative, antimigratory, and antiangiogenic properties and inhibits metastasis and angiogenesis-associated proteases in renal cancer. J Biol Inorg Chem. 2018;23:399-411.

59. Vanicek S, Kopacka H, Wurst K, et al. Cobaltoceniumethynyl gold(I) as an unusual heterodinuclear bioorganometallic fragment to study the biological properties of alkynyl gold complexes. Dalton Trans. 2016;45:1345-1348.

60. Meyer A, Gutierrez A, Ott I, Rodriguez L. Phosphine-bridged dinuclear gold(I) alkynyl complexes: thioredoxin reductase inhibition and cytotoxicity. Inorg Chim Acta. 2013;398:72-76.

61. Balasingham RG, Williams CF, Mottram HJ, Coogan MP, Pope SJA. Gold(I) complexes derived from Alkynyloxy-substituted Anthraquinones: syntheses, luminescence, preliminary cytotoxicity, and cell imaging studies. Organometallics. 2012;31:5835-5843.

62. Hikisz P, Szczupak L, Koceva-Chyla A, et al. Anticancer and antibacterial activity studies of gold(I)-Alkynyl Chromones. Molecules. 2015;20:19699-19718.

63. Mirzadeh N, Priver SH, Abraham A, Shukla R, Bansal V, Bhargava SK. Linking flavonoids to gold - a new family of gold compounds for potential therapeutic applications. Eur J Inorg Chem. 2015;4275-4279.

64. Kowalski K, Szczupak L, Bernas T, Czerwieniec R. Luminescent rhenium(I)chromone bioconjugate: synthesis, photophysical properties, and confocal luminescence microscopy investigation. J Organomet Chem. 2015;782:124-130.

65. Langdon-Jones EE, Lloyd D, Hayes AJ, et al. Alkynyl-naphthalimide fluorophores: gold coordination chemistry and cellular imaging applications. Inorg Chem. 2015;54:6606-6615.

66. Fernandez-Moreira V, Marzo I, Gimeno MC. Luminescent Re(I) and Re(I)/Au(I) complexes as cooperative partners in cell imaging and cancer therapy. Chem Sci. 2014;5:4434-4446.

67. Oehninger L, Rubbiani R, Ott I. N-heterocyclic carbene metal complexes in medicinal chemistry. Dalton Trans. 2013;42:3269-3284.

68. Cinellu MA, Ott I, Casini A. Gold orgnametallics with biologycal properties. In: Jaouen G, Salmain M, eds. Biorganometallic Chemistry. Weinheim: Wiley-VCH; 2014:117-140.

69. Liu WK, Gust R. Update on metal N-heterocyclic carbene complexes as potential anti-tumor Metallodrugs. Coord Chem Rev. 2016;329:191-213.

70. Visbal R, Gimeno MC. N-heterocyclic carbene metal complexes: photoluminescence and applications. Chem Soc Rev. 2014;43:3551-3574.

71. Estrada-Ortiz N, Guarra F, de Graaf IAM, et al. Anticancer gold N-heterocyclic Carbene complexes: a comparative in vitro and ex vivo study. ChemMedChem. 2017;12:1429-1435.

72. Dasari S, Tchounwou PB. Cisplatin in cancer therapy: molecular mechanisms of action. Eur J Pharmacol. 2014;740:364-378.

73. Kostova I. Platinum complexes as anticancer agents. Recent Pat Anticancer Drug Discov. 2006;1:1-22.

74. Jurgens S, Kuhn FE, Casini A. Cyclometalated complexes of platinum and gold with biological properties: state-of-the-art and future perspectives. Curr Med Chem. 2018;25:437-461. 
75. Ma DL, Shum TYT, Zhang F, Che CM, Yang M. Water soluble luminescent platinum terpyridine complexes with glycosylated acetylide and arylacetylide ligands: photoluminescent properties and cytotoxicities. Chem Commun. 2005;4675-4677.

76. Klein A, Lüning A, Ott I, et al. Organometallic palladium and platinum complexes with strongly donating alkyl coligands E synthesis, structures, chemical and cytotoxic properties. J Organomet Chem. 2010;695:1898-1905.

77. Butsch K, Elmas S, Sen Gupta N, et al. Organoplatinum(II) and -palladium(II) complexes of nucleobases and their derivatives. Organometallics. 2009;28:3906-3915.

78. Lüning A, Schur J, Hamel L, Ott I, Klein A. Strong cytotoxicity of organometallic platinum complexes with Alkynyl ligands. Organometallics. 2013;32:3662-3672.

79. Vezzu DAK, Lu Q, Chen YH, Huo S. Cytotoxicity of cyclometalated platinum complexes based on tridentate NCN and CNN-coordinating ligands: remarkable coordination dependence. J Inorg Biochem. 2014;134:49-56.

80. Bai L, Gao C, Liu Q, et al. Research progress in modern structure of platinum complexes. Eur J Med Chem. 2017;140:349-382.

81. Sun RWY, Chow ALF, Li XH, Yan JJ, Chui SSY, Che CM. Luminescent cyclometalated platinum(II) complexes containing -heterocyclic carbene ligands with potent in vitro and in vivo anti-cancer properties accumulate in cytoplasmic structures of cancer cells. Chem Sci. 2011;2:728-736.

82. Muro ML, Rachford AA, Wang X, Castellano FN. Platinum ${ }^{\mathrm{II}}$ acetylide photophysics. In: Lees A, ed. Photophysics of Organometallics. Berlin Heidelberg: Springer-Verlag; 2009:159-191. Topics in Organometallic Chemistry; 29.

83. Chen ZF, Qin QP, Qin JL, et al. Stabilization of G-quadruplex DNA, inhibition of telomerase activity, and tumor cell apoptosis by organoplatinum(II) complexes with oxoisoaporphine. J Med Chem. 2015;58:2159-2179.

84. Kieltyka R, Englebienne P, Fakhoury J, Autexier C, Moitessier N, Sleiman HF. A platinum Supramolecular Square as an effective G-Quadruplex binder and telomerase inhibitor. J Am Chem Soc. 2008;130:10040-10041.

85. Pendino F, Tarkanyi I, Dudognon C, et al. Telomeres and telomerase: pharmacological targets for new anticancer strategies? Curr Cancer Drug Targets. 2006;6:147-180.

86. Kieltyka R, Fakhoury J, Moitessier N, Sleiman HF. Platinum phenanthroimidazole complexes as G-quadruplex DNA selective binders. Chem - EurJ. 2008;14:1145-1154.

87. Ou Z, Wang Y, Gao Y, et al. Targeting human telomeric and C-Myc G-Quadruplexes with alkynylplatinum(II) terpyridine complexes under molecular crowding conditions. J Inorg Biochem. 2017;166:126-134.

88. Ou Z, Feng Z, Liu G, et al. Synthesis and G-quadruplex-binding properties of cationic platinum(II) terpyridine complexes containing $\sigma$-alkynyl auxiliaries. Chem Lett. 2015;44:425-427.

89. Ou ZZ, Ju BL, Gau YY, Wang ZC, Huang G, Qian YM. Alkynylplatinum(II) 2,6Bis(N-ethylbenzimidazol-2'-yl)pyridine complexes: effect of alkynyl ligand on G-quadruplex binding properties and anticancer activity. Acta Phys-Chim Sin. 2015;31:2386-2394.

90. Bhowmick S, Jana A, Marri SR, et al. Pyrazine based Pt(II) bis-alkynyl organometallic complexes: synthesis, characterization, and cytotoxic effect on A549 human lung carcinoma cells. Appl Organomet Chem. 2017;31:e3824.

91. Mitra K, Basu U, Khan I, Maity B, Kondaiah P, Chakravarty AR. Remarkable anticancer activity of ferrocenylterpyridine platinum(II) complexes in visible light with low dark toxicity. Dalton Trans. 2014;43:751-763.

92. Maity B, Chakravarthi BVSK, Roy M, Karande AA, Chakravarty AR. DNA photocleavage and cytotoxic properties of ferrocene conjugates. Eur J Inorg Chem. 2011;1379-1386. 
93. Mitra K, Shettar A, Kondaiah P, Chakravarty AR. Biotinylated platinum(II) ferrocenylterpyridine complexes for targeted photoinduced cytotoxicity. Inorg Chem. 2016;55:5612-5622.

94. Tripodo G, Mandracchia D, Collina S, Ruiand M, Rossi D. New perspectives in cancer therapy: the biotin-antitumor molecule conjugates. Med Chem. 2014;S1-004. https://doi.org/10.4172/2161-0444.

95. Ren WX, Han J, Uhm S, et al. Recent development of biotin conjugation in biological imaging, sensing, and target delivery. Chem Commun. 2015;51:10403-10418.

96. Ramu V, Gautam S, Garai A, Kondaiah P, Chakravarty AR. Glucose-appended platinum(II)-BODIPY conjugates for targeted photodynamic therapy in red light. Inorg Chem. 2018;57:1717-1726.

97. Kamkaew A, Lim SH, Lee HB, Kiew LV, Chung LY, Burgess K. Bodipy dyes in photodynamic therapy. Chem Soc Rev. 2013;42:77-88.

98. Raza MK, Mitra K, Gautam S, Garai A, Kondaiah P, Chakravarty AR. Monofunctional BODIPY-appended imidazoplatin for cellular imaging and mitochondriatargeted photocytotoxicity. Inorg Chem. 2017;56:11019-11029.

99. Macheda ML, Rogers S, Best JD. Molecular and cellular regulation of glucose transporter (GLUT) proteins in Cancer. J Cell Physiol. 2005;202:654-662.

100. Mahalingam SM, Ordaz JD, Low PS. Targeting of a photosensitizer to the mitochondrion enhances the potency of photodynamic therapy. ACS Omega. 2018;3: 6066-6074. 